
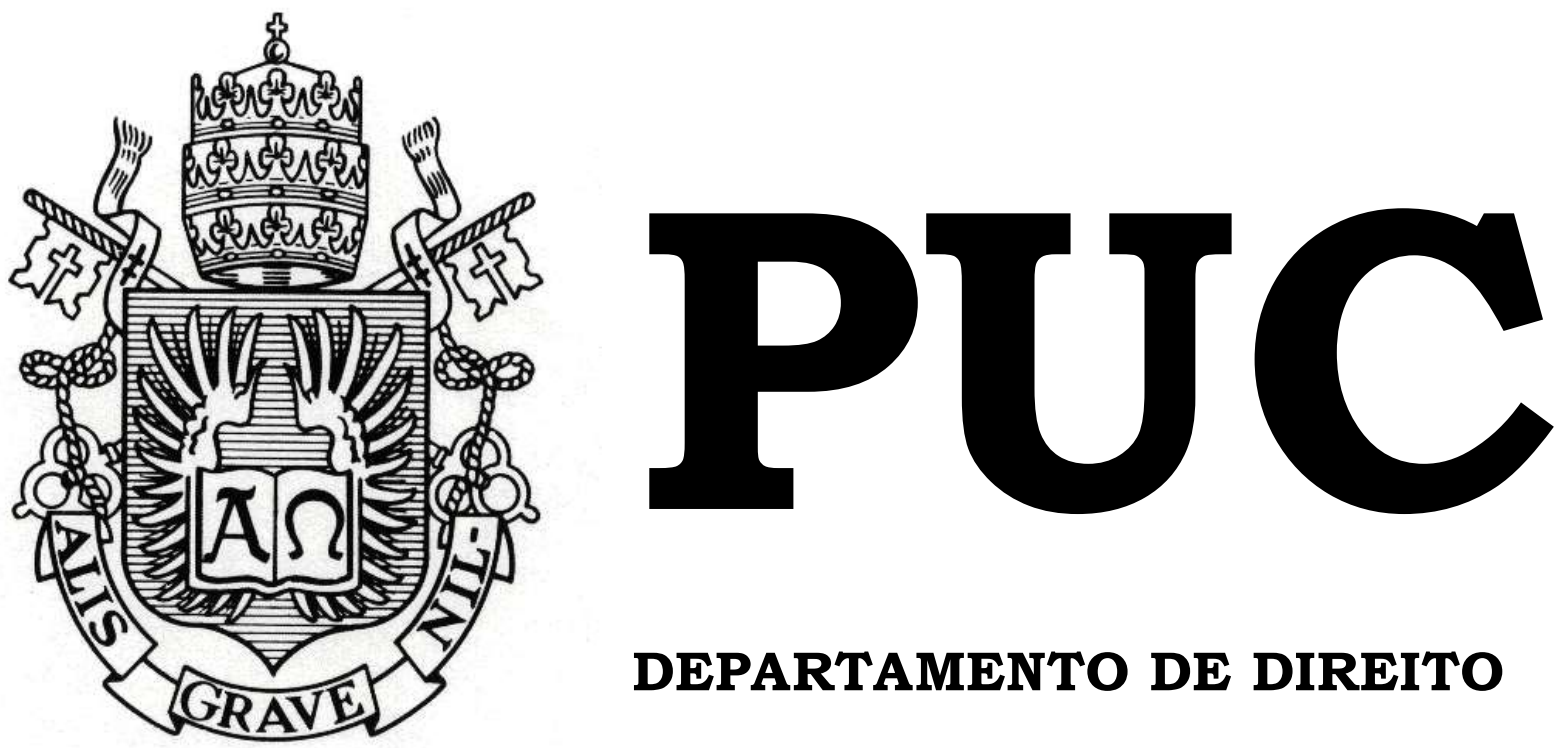

DEPARTAMENTO DE DIREITO

LEI DE ANISTIA:

O ALCANCE DOS ANISTIADOS E A CONTROVERSA DECISÃO DO SUPREMO TRIBUNAL FEDERAL NA ADPF 153

Por

DEBORAH TORRES LEAL

ORIENTADORA: REGINA COELI SOARES

2016.2

PONTIFÍCIA UNIVERSIDADE CATÓLICA DO RIO DE JANEIRO RUA MARQUÊS DE SÃO VICENTE, 225 - CEP 22451-900 RIO DE JANEIRO - BRASIL 


\title{
LEI DE ANISTIA: \\ O ALCANCE DOS ANISTIADOS E A CONTROVERSA DECISÃO DO SUPREMO TRIBUNAL FEDERAL NA ADPF 153
}

\author{
por \\ DEBORAH TORRES LEAL
}

Monografia apresentada ao Departamento de Direito da Pontifícia Universidade Católica do Rio de Janeiro (PUC-Rio) como requisito parcial para obtenção do título de Bacharel em Direito

Orientadora: Regina Coeli Lisboa Soares 
À minha família, por todo o apoio e amor, especialmente ao meu pai, inspiração para que eu me debruçasse sobre este tema. 


\section{RESUMO}

O presente trabalho tem por objetivo questionar a inclusão dos agentes militares que praticaram crimes comuns no rol da Lei de Anistia (6.683/79) e a controvertida decisão do Supremo Tribunal Federal em ação proposta pela $\mathrm{OAB}$ ao não revisar este entendimento. Para isso, serão enfatizados os princípios basilares da Constituição de 1988 e do Estado Democrático de Direito, os Direitos Humanos e o contexto e intenções obscuras em que a Lei foi promulgada.

Palavras-Chave: Direito Constitucional. Lei de Anistia. Ditadura Civil-Militar. Arguição de Descumprimento de Preceito Fundamental $n^{\circ} 153$ (ADPF 153). Dignidade da Pessoa Humana. Direitos Humanos. 


\section{SUMÁRIO}

LISTA DE ABREVIATURAS E SIGLAS ..................................................6

1 Introdução .............................................................................................. 7

2 Contexto Histórico-Político .............................................................................9

2.1 Momentos Antecedentes ao Golpe .....................................................

2.2 A Ditadura Militar e os Atos Institucionais ......................................220

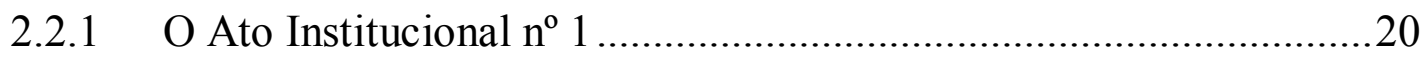

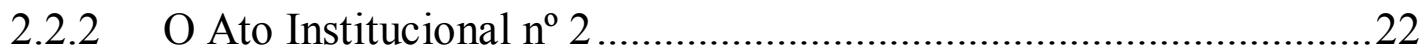

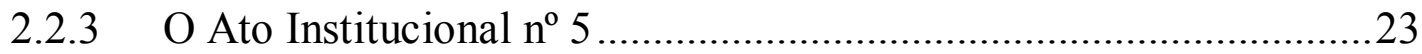

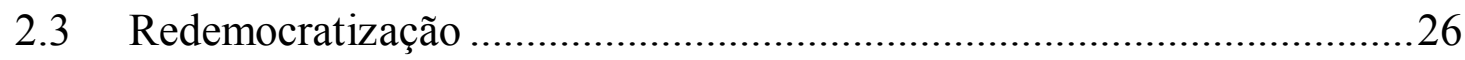

3 A Constituição Federal de 1988 ...............................................................28

3.1 Assembleia Nacional Constituinte .....................................................28

3.2 A Dignidade da Pessoa Humana ........................................................ 30

3.2.1 Aspecto Individualista ........................................................ 30

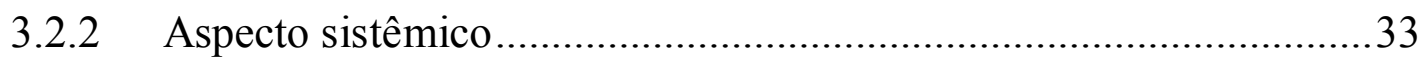

3.3 Princípios Republicano e Democrático ................................................34

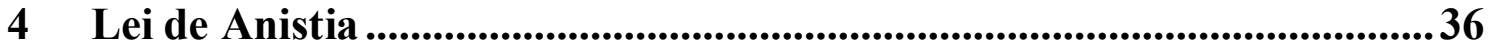

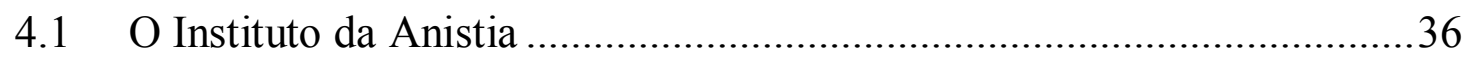

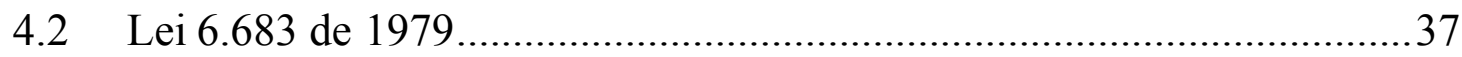

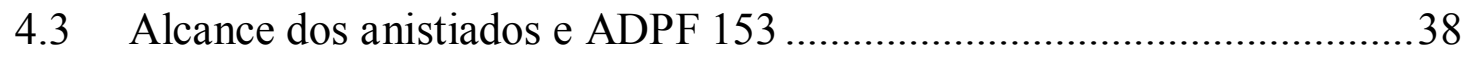

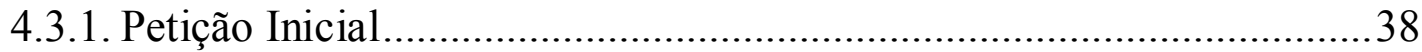

4.3.2. Síntese das informações dadas pela Câmara dos Deputados, Advocacia

Geral da União e Senado Federal ..........................................................4 44

4.3.3. Improcedência da ADPF e os votos dos ministros ...........................4 47

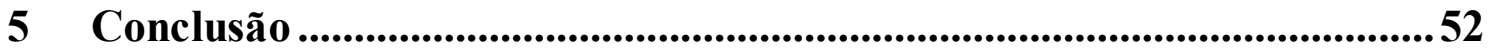

REFERÊNCIAS BIBLIOGRÁFICAS ........................................................... 60 


\section{LISTA DE ABREVIATURAS E SIGLAS}

$\begin{array}{ll}\text { ADPF } & \text { Arguição de Descumprimento de Preceito Fundamental } \\ \text { OAB } & \text { Ordem dos Advogados do Brasil } \\ \text { STF } & \text { Supremo Tribunal Federal } \\ \text { UDN } & \text { União Democrática Nacional } \\ \text { PTB } & \text { Partido Trabalhista Brasileiro } \\ \text { PSB } & \text { Partido Social Democrático } \\ \text { SUPRA } & \text { Superintendência da Política Agrária } \\ \text { PMDB } & \text { Partido do Movimento Democrático Brasileiro } \\ \text { PDS } & \text { Partido Social Democrático } \\ \text { ONU } & \text { Organização das Nações Unidas }\end{array}$




\section{Introdução}

Faz pouco mais de trinta anos desde que se iniciou o processo de redemocratização no Brasil após a ditadura civil militar. Apesar de as eleições diretas só ocorrerem em 1989, uma grande conquista para a inauguração do Estado Democrático de Direito foi a promulgação da Constituição de 1988.

Ainda que tenha havido intensa pressão e mobilização de diversos setores da sociedade no sentido de se cobrar a anistia, foi ainda durante a vigência do regime de exceção e sob a Constituição outorgada de 1967 que a Lei 6.683 foi promulgada, na data de 28 de agosto de 1979 .

É cediço que, como todo regime de exceção, a ditadura civil militar foi palco para a execução de diversos crimes, em grande parte praticados pelo próprio Estado sob o pretexto de manutenção da ordem institucional. Ocorreu que apesar de a Lei de Anistia atender aos anseios populares que cobravam esse instituto, beneficiou também os próprios agentes estatais responsáveis por tais crimes.

A inclusão desses agentes no rol de anistiados da Lei foi objeto de uma Arguição de Descumprimento de Preceito Fundamental (ADPF) interposta pela Ordem dos Advogados do Brasil (OAB) em 28 de outubro de 2008. Na ADPF 153 o Supremo Tribunal Federal julgou improcedente a revisão da interpretação da Lei de Anistia.

O que se almeja aqui é estimular a reflexão sobre essa decisão e, consequentemente, sobre o alcance e abrangência de quem deveria ser contemplado pela Lei $6.683 / 79$, bem como explicitar as gravosas consequências de anistiar os representantes do Estado que praticaram crimes comuns violadores dos direitos humanos. 
Para cumprir tal objetivo, o trabalho foi dividido em três partes. Primeiro, para iniciar o estudo, foi necessário explicitar o contexto histórico em que a Lei de Anistia foi promulgada, evidenciando os momentos antecedentes ao golpe de 1964, o regime militar e seus Atos Institucionais, e o período de redemocratização. Tal contextualização é fundamental para que possamos, após, questionar de maneira mais aprofundada a decisão da ADPF 153.

$\mathrm{Na}$ segunda parte foi preciso adentrar em princípios basilares da nossa Constituição de 1988 e do Estado Democrático de Direito, tais como o princípio da dignidade da pessoa humana e os princípios democrático e republicano. Essa inclusão foi feita para que compreendamos melhor os preceitos fundamentais elencados pela Ordem dos Advogados do Brasil na ADPF 153 e para que percebamos suas fundamentais importâncias para o Estado Democrático de Direito.

Após, adentramos na Lei 6.683/79, com uma breve explicação sobre o que vem a ser o instituto da anistia, sua utilização no Brasil e a Arguição de Descumprimento de Preceito Fundamental $n^{0}$ 153, apresentando uma síntese da petição inicial e os argumentos defendidos pela OAB, as manifestações no processo e a sua decisão.

Por fïm, na conclusão há uma análise crítica da decisão do Supremo Tribunal Federal na mencionada ação e, consequentemente, o fechamento do trabalho. 


\section{Contexto Histórico-Político}

\subsection{Momentos Antecedentes ao Golpe}

Já nas eleições de 1960 era possível observar a divisão de diferentes grupos políticos no país, que no futuro viriam a compor, concomitantemente com outros fatores, bases do golpe militar de 1964.

A União Democrática Nacional - UDN, partido político criado em 1945, inicialmente buscava servir de oposição ao regime do Estado Novo de Getúlio Vargas. Na área econômica prezava pelos interesses dos proprietários de terra e pela abertura econômica para o capital estrangeiro, adotando postura liberal e privatizante. Conhecido por defender um liberalismo clássico e dotado de grande conservadorismo e apego ao moralismo, em governos democraticamente eleitos normalmente eram partido de oposição.

Em contrapartida, o Partido Trabalhista Brasileiro - PTB, igualmente fundado no ano de 1945, tinha como inspiração a figura de Getúlio Vargas e como um dos objetivos servir de suporte para a classe popular e trabalhadora; de modo a unir os operários urbanos. Sob forte influência de Vargas, adotava o ideal nacionalista e, posteriormente, houve um maior extremismo e consequente aproximação com o comunismo.

O terceiro partido político protagonista do período foi o Partido Social Democrático - PSD, criado no mesmo ano e grupo de maior representatividade na Câmara dos Deputados, era contrário às ideias da UDN e buscava um equilíbrio entre conservadorismo e os avanços almejados.

No fim do governo de Juscelino, o grande protagonista das eleições foi o seu candidato de oposição Jânio Quadros. Nascido em 1941 no Mato 
Grosso do Sul e formado em direito, Jânio era figura intrigante e carismática. Seu lema e "jingle" na campanha à presidência era "varrer a corrupção", usando uma vassoura como símbolo da limpeza que prometia realizar na política.

Apesar de suas características singulares e notória simpatia, Jânio Quadros foi um tanto contraditório em sua trajetória política: ora filiado ao PTB ora à UDN, defendia uma espécie de "populismo de direita", militarista, antiparlamentar e associado ao grande capital.

À época apoiado pela União Democrática Nacional, Quadros candidatou-se à presidência, mas explicou que não prejudicaria a sua independência com apoios partidários. Pouco tempo depois, todavia, rompeu com o partido por conta de um desentendimento entre este e o Partido Democrata Cristão.

Com seu jeito irreverente e carisma, o candidato conquistou simpatia e provocou animação na população, especialmente na burguesia. Jânio Quadros é, então, eleito como Presidente da República em 3 de outubro de 1960 com pouco mais de $48 \%$ dos votos do eleitorado. Como vicepresidente o eleito foi João Goulart, que vencera o candidato Milton Campos, da UDN, por pouca margem de diferença.

Ocorreu que a contradição do novo Presidente ficou cada vez mais evidente. Jânio passou a tomar decisões desacertadas e sem qualquer coerência, aproximando-se ora do conservadorismo e moralismo da UDN, ora do populismo do PTB ou até da burocracia do PSD. Aliada a essa falta de linearidade do governo, Quadros tomou uma série de medidas desnecessárias e polêmicas, como um decreto proibindo o uso de biquínis em praias do Rio de Janeiro.

Importante ressaltar que o país passava por um período em que precisava de medidas eficazes para que se mantivesse estável 
economicamente. Economia esta que, por sua vez, encontrava-se cada vez mais fragilizada.

O Presidente passou, então, a enfrentar intensa oposição dos partidos, e pela primeira vez o governo não tinha mais maioria no Congresso. Além de nada fazer para reverter esse grave quadro, Jânio piorou a sua situação dentro da política do país quando levamos em conta o modo como lidava com a política externa.

Sua política internacional alternativa pretendia firmar relações comerciais e diplomáticas com todas as nações do mundo e buscava um maior estreitamento com países de regime socialista. Ainda que nisso houvesse boas intenções do Presidente, o momento não era propício, considerando a polarização em que se encontrava o mundo.

Os sucessivos equívocos embaraçosos do governo independente de Quadros foram motivo de insatisfação e revolta. Carlos Lacerda, então governador da Guanabara eleito pela UDN, tornou-se forte oposição e confronto direto ao Presidente, passando a atacá-lo publicamente e aumentando a sua falta de credibilidade perante o país.

As errôneas atitudes tomadas por Jânio Quadros eram mal calculadas pelo Presidente. A condecoração de Ernesto Che Guevara por Jânio Quadros foi o "clímax" e momento de tensão que acirrou as disputas ideológicas entre os partidos do governo e provocaram, por fim, uma ruptura entre eles.

Um governo repleto de ambiguidades e contradições não poderia terminar de maneira diferente: apenas sete meses após sua posse, Jânio renuncia. Apesar de alegar, em sua carta de renúncia, que "forças ocultas" foram as responsáveis por sua decisão, muito se questiona acerca dos verdadeiros motivos e se a sua real intenção seria a de retornar aclamado pelo povo - o que ficou longe de acontecer, uma vez que o Congresso 
aceitou prontamente a sua decisão e a classe mais conservadora não tomou qualquer atitude, permanecendo inerte.

Além do povo brasileiro, um grande interessado nesse acontecimento era o seu vice João Goulart: fora do Brasil e na madrugada de 26 de agosto daquele ano, recebeu a notícia da renúncia. Jango havia ido fazer uma visita oficial à China, país de ideologia comunista e repelido pelos militares brasileiros e pelos Estados Unidos.

Se Goulart estivesse no Brasil, talvez pudéssemos ter esperança de uma transição menos traumática ${ }^{1}$, mas o fato de ele estar em um país comunista fez com que houvesse imediata resistência ao novo governo. É suspeito, por essas razões, que Jânio tenha escolhido propositalmente esse momento para fazer a renúncia, o que confirmaria as teses de que voltar “nos braços do povo” era a verdadeira intenção do antigo Presidente.

Seu plano seria o de ocorrer um vazio na sucessão da presidência justamente porque o vice estava em missão oficial na China, deixando o país “órfão" e fazendo com que Jânio voltasse com poderes autoritários.

Nesse momento se iniciou uma crise no sistema político brasileiro. Para os ministros militares, Goulart na Presidência significava constante e real ameaça. Apesar de se deparar com grande resistência, entretanto, Jango pôde contar com o significativo apoio do governador Leonel Brizola, que encabeçou a chamada Campanha da Legalidade, movimento iniciado no Rio Grande do Sul pela posse do novo Presidente, impedindo que o golpe ocorresse de imediato.

João Goulart assume, então, a Presidência sob o regime parlamentarista, o que seria alterado após vitória esmagadora do presidencialismo no plebiscito de 1963, passando a ter o Presidente todos os poderes outorgados pela Constituição de 1946.

\footnotetext{
${ }^{1}$ SANDER, Roberto. O verão do golpe. $2^{\text {a }}$ Ed. Rio de Janeiro: Maquinária, 2013. p. 28.
} 
Mesmo após a sua posse, entretanto, o quadro político era instável. Em março de 1963 o Presidente propôs ao Congresso a aprovação do projeto de reforma agrária, que mesmo após pressão e mobilização de grupos de esquerda, foi recusado. Tal decisão deixou ainda mais evidente a cisão que existia no país entre grupos de esquerda e de direita e a ínfima possibilidade de haver uma reforma constitucional.

$\mathrm{O}$ radicalismo se intensificara e, para líderes mais extremistas como Leonel Brizola, a única solução para um avanço significativo nas demandas sociais era o confronto direto.

Jango não tinha apenas que enfrentar a resistência da direita do país como também tinha o desafio de conciliar as suas medidas reformistas com os interesses econômicos dos Estados Unidos, o que acabou sendo inviável. Ao regulamentar a Lei de Remessas de Lucros, o Presidente aumentou a cisão com este país e sofreu de imediato a retaliação norte-americana, que cortou todo e qualquer crédito ao governo.

Mais um evento responsável por trazer repercussão negativa ao governo de Jango foi um movimento de politização da baixa hierarquia da Marinha e da Aeronáutica que culminou em uma rebelião. Tal movimento foi encarado como uma quebra de princípios da hierarquia militar, ação intolerável e que fez com que houvesse um recuo dos militares legalistas em suas conviç̧ões nacionalistas.

A partir de então, o Presidente se viu encurralado: sem apoio da direita ou da esquerda, esvaindo cada vez mais a sua governabilidade e credibilidade.

A economia continuava mal e as conspirações contra Goulart, já existentes desde a renúncia de Jânio Quadros, intensificaram-se ainda mais. 
Em dezembro de 1963, os Estados Unidos chegaram a cogitar uma intervenção militar, deixando a situação política do país ainda mais tensa ${ }^{2}$.

Apesar da visível instabilidade política e desconfiança de que um golpe estava sendo tramado, aparentemente tudo levava a crer que Jango permaneceria no poder até o fim de seu governo em 1966. O general Assis Brasil, chefe da Casa Militar, mantinha-se confiante e, visando acalmar o Presidente, repetia que seu dispositivo militar era imbatível ${ }^{3}$.

Apesar do otimismo de Goulart, a resistência ao governo crescia como uma "onda silenciosa" 4 , com reuniões de militares insatisfeitos tramando contra o governo. A oposição ao Presidente passou, inclusive, a ficar mais evidente na imprensa, momento em que jornais de grande visibilidade passaram a abrir espaço para críticos ferrenhos do governo.

Mesmo sob forte pressão, Jango prosseguia com o seu objetivo de ver aprovadas as reformas de base. No início do ano de 1964, Goulart terminou o decreto de desapropriação de terras e, posteriormente, foram assinados os convênios de assistência técnica à reforma agrária.

Todo esse cenário influenciou em uma consequente união dos trabalhadores rurais, que davam todo o respaldo ao Presidente - as Ligas Camponesas tinham uma organizada estrutura e acabavam por formar uma base política significativa para a reforma no campo.

Enquanto o diálogo com a UDN parecia impossível, o PSD apresentava receio com relação à reforma. Membros do partido temiam que, se realizada, a reforma agrária fosse motivo de pregação ideológica, o que iria contra o próprio partido.

Roberto Sander relata que houve trabalho de doutrinação ideológica alertando para o chamado "perigo vermelho". Havia exibição de filmes em

\footnotetext{
${ }^{2}$ SANDER, Roberto. O verão do golpe. $2^{\mathrm{a}}$ Ed. Rio de Janeiro: Maquinária, 2013. p. 37.

${ }^{3}$ Ibid, p. 41.

${ }^{4}$ Ibid, p. 43.
} 
quartéis, bases e escolas; e, para a população de modo geral, em praças do interior do país. ${ }^{5}$

Enquanto isso, o relacionamento entre Brizola e Goulart continuava estremecido. Enquanto o primeiro pregava a necessidade do conflito armado, alegando que se continuassem inertes um golpe viria, o segundo acreditava no diálogo e evitava o que chamava de um derramamento inútil de sangue.

Em meio ao caos em que o país se encontrava, Jango assinou a Lei de Remessa de Lucros, fazendo com que passassem a ser considerados nacionais os lucros de reinvestimento de empresas estrangeiras, afrontando diretamente os interesses de investidores estrangeiros, inclusive os dos Estados Unidos.

Já quase no mês de fevereiro de 1964, o Presidente começou a perceber que já não existia chance de um diálogo ou negociação. Jango estava mesmo encurralado: acometido pela direita e sem apoio considerável do PSD para que pudesse efetivar as suas tão sonhadas reformas de base, resolveu por se dedicar inteiramente às raízes trabalhistas.

Em um encontro em seu apartamento com sindicalistas, o presidente da Supra João Pinheiro Neto e José Gomes Talarico, Goulart informou sua intenção e passou a decidir providências com relação a um comício na Central do Brasil. Com o apoio do ministro da Guerra, era a chance de robustecer a autoridade do Presidente.

A data do comício foi marcada e os jornais de grande circulação passaram a estampar o anúncio em suas capas: dia 13 de março Jango falaria na Central do Brasil pelas reformas de base.

Foi nesse mesmo período que a direita se uniu ainda mais, conspirando para que o governo chegasse ao fim o quanto antes. Os

${ }^{5}$ SANDER, Roberto. O verão do golpe. $2^{\mathrm{a}}$ Ed. Rio de Janeiro: Maquinária, 2013. p. 57. 
opositores de Goulart firmaram um acordo militar com os Estados Unidos, que previa o assessoramento do país caso houvesse ameaça à segurança do Brasil.

Enquanto a direita permanecia unida em busca de um mesmo objetivo, a esquerda estava enfraquecida: Goulart e Brizola viam sua relação mais estremecida do que nunca, já que o segundo insistia na ideia de que era preciso que houvesse uma revolução clássica de esquerda e Jango permanecia convicto ao afirmar que a mudança deveria ser feita por meio do diálogo com todos os setores da sociedade. Segundo Sander, essa relação instável dos dois refletia a desunião da esquerda. ${ }^{6}$

Já no mês de fevereiro, o governo explicita sua disposição em convocar um plebiscito acerca do direito de voto dos analfabetos. Para Jango, esse plebiscito funcionaria como um instrumento para que a população deixasse claro o seu apoio às reformas de base, aumentando as chances de serem realizadas.

Houve, no mesmo dia, divulgação na imprensa da ideia do governo de reatar relações com a China Comunista, dando prosseguimento ao acordo de cooperação econômica firmado com os chineses anos atrás, na fatídica viagem em que soube da renúncia do até então Presidente Jânio Quadros.

Além de toda essa efervescência política, os conflitos entre camponeses e latifundiários se intensificaram e um quadro de guerra de classes robustecera todo o receio das elites. $\mathrm{O}$ acirramento e disputa no interior do Brasil ganhava contornos de guerra civil e tinha dimensão internacional, repercutindo na imprensa estrangeira.

Em meio a tudo isso, Jango anunciou um programa popular fundado em três pontos cruciais: enfrentar problemas recorrentes das grandes 
cidades - como transporte público e construção de casas populares -, favorecer o abastecimento dos gêneros de primeira necessidade e moderar o crescente aumento de preço desses produtos.

O intenso conflito entre o governo e a oposição parecia não ter fim: sendo a reforma agrária a maior protagonista dessa divergência, o acirramento político parecia estar chegando a um esgotamento.

Com a chegada do mês de março, havia grande expectativa e desconfiança para o dia 13: momento em que Jango faria o comício na Central do Brasil objetivando demonstrar o apoio popular às reformas de base e pressionar o Congresso. Chegado o grande dia, quase $200 \mathrm{mil}$ pessoas estavam reunidas à Praça Cristiano Otoni, região central do Rio de Janeiro. Havia excitação e expectativa naquela multidão que se aglomerava; e desconfiança na oposição.

Goulart havia conseguido reunir para participação no comício os principais líderes sindicais e militantes pelas reformas de base: o governador de Pernambuco Miguel Arraes foi o primeiro a discursar, seguido pelo entusiasta Leonel Brizola. Depois deles, foi a vez do Presidente. Acompanhado da esposa Teresa Goulart, Jango discursou por pouco mais de uma hora e foi ovacionado pela plateia, que estava entusiasmada com suas palavras.

No fim de seu discurso, o Presidente ratificou sua intenção de realizar a reforma agrária, eleitoral, tributária, estudantil e educacional; confirmou sua luta pelo direito de voto dos analfabetos e pela independência econômica do país. Imediatamente após o fím do comício, a direita se viu acorrentada.

Passado algum tempo, todavia, os setores conservadores voltaram às conspirações. O governador Carlos Lacerda convocava o povo, os militares 
e o Congresso a se voltarem contra o governo, alegando que Jango teria, agora, passado de todos os limites.

Como era de se esperar, o comício da Central do Brasil repercutiu negativamente nos Estados Unidos, que o interpretaram como um aceite à colaboração do Partido Comunista e de grupos radicais. Em pouco tempo, o país americano não hesitaria em apoiar a deposição de Goulart e instituição do golpe.

A "onda silenciosa" da direita continuava firme e forte, avançando em silêncio para ver o governo acabado. Apenas seis dias após o comício e como resposta a ele, no dia 19 de março houve a "Marcha da Família com Deus pela Liberdade". Um movimento que congregou entre 300 e $500 \mathrm{mil}$ pessoas ocupou as ruas da capital de São Paulo contra uma suposta ameaça comunista e as políticas de governo de João Goulart.

No dia 20 de março, o general Jair Dantas, ministro de guerra, pediu licença do posto que ocupava para tratar um problema de saúde. Segundo Roberto Sander, é suspeito que o general já soubesse das reais intenções do general Castello Branco de dar o golpe, escolhendo propositalmente se afastar do governo naquele momento para que não fosse visto como um traidor da confiança do Presidente. ${ }^{7}$

Ainda no mês de março houve revolta dos marinheiros, que, reunidos no Sindicato dos Metalúrgicos, demonstravam a insatisfação com relação aos baixos salários e à excessiva rigidez dos regulamentos disciplinares; fazendo, ao mesmo tempo, discursos inflamados a favor do governo. Tal episódio foi visto como um ato subversivo e de desobediência, enfraquecendo ainda mais o governo e fazendo com que a revolta se tornasse um estopim para o golpe que se aproximava.

\footnotetext{
${ }^{7}$ SANDER, Roberto. $O$ verão do golpe. $2^{\text {a }}$ Ed. Rio de Janeiro: Maquinária, 2013. p. 151.
} 
Segundo "João Goulart, uma biografia", de Jorge Ferreira, houve um encontro entre Jango, Tancredo Neves e João Pinheiro Neto, e, em dado momento, Tancredo aconselhou:

(...). Faça o jogo dos insubordinados e garanto que seu governo talvez não chegue ao final do mês. É a verdade... e o meu dever é o de lhe dizer a verdade. Agora, a decisão é sua, responsabilidade intransferível. A História para o bem ou para o mal, mas sempre fria e isenta, saberá julgar a sua pessoa conforme a atitude que tomar nestes turbulentos instantes da vida brasileira. Em primeiro lugar, a História julgará a sua pessoa, você é o chefe. $\mathrm{O}$ resto, todos nós, não passamos de meros coadjuvantes. ${ }^{8}$

Àquela altura, com a esquerda desunida e a direita coesa - com apoio irrestrito dos Estados Unidos -, o golpe militar estava cada vez mais perto. Como reação, então, ao discurso de Jango para os sargentos na reunião realizada no Automóvel Clube do Brasil, as tropas do general Mourão Filho já marchavam em direção ao Rio de Janeiro no dia 31 de março.

O que acabou ocorrendo não foi uma decisão impensada, mas um movimento que há muito vinha se delineando e tomando forma, acelerado depois do comício da Central do Brasil e tendo como estopim a revolta dos marinheiros.

Apesar de Leonel Brizola defender uma resistência, o Presidente, temendo um derramamento inútil de sangue em defesa de seu mandato, não viu outra saída que não a de sair do país. A queda foi consumada e a ditadura militar implantada. O golpe havia sido feito.

\section{Segundo Roberto Sander:}

Era uma guerra de ideologias envolvendo os mais diversos atores, com João Goulart na posição de presidente, sendo o alvo de todos os ataques. Para a direita, civil e militar, ele era o responsável pela baderna política, pela inflação, pela quebra de hierarquia das Forças Armadas. Para a esquerda mais radical, era um burguês moderado e populista. Nesse embate, prevaleceu a força dos interesses internacionais, da ala direitista dos militares e das classes dominantes, em detrimento de um governo que, de alguma forma, tentava ampliar a participação popular no processo de desenvolvimento do país. ${ }^{9}$

\footnotetext{
${ }^{8}$ NETO, João Pinheiro. Jango - um depoimento pessoal. p. 112.

${ }^{9}$ SANDER, Roberto. O verão do golpe. $2^{\mathrm{a}}$ Ed. Rio de Janeiro: Maquinária, 2013. p. 236.
} 


\subsection{A Ditadura Militar e os Atos Institucionais}

O golpe que pôs fim ao governo democraticamente instalado por meio das eleições de 1960 foi feito e a ditadura militar instaurada. A sociedade estava claramente dividida e os jornais de grande circulação noticiavam em tom festivo o que chamavam de "ressurgimento da democracia".

O principal objetivo dos militares era o de retirar João Goulart da presidência da república para então realizar o que chamavam de "limpeza" nas instituições. Com um novo grupo no poder, fazia-se necessária a realização de medidas para instrumentalizar suas finalidades.

\subsubsection{O Ato Institucional $n^{\circ} 1$}

Foi assinado, então, pelo general Arthur da Costa e Silva no dia 9 de abril de 1964 o primeiro Ato Institucional. Conhecido atualmente como AI1, dentre suas medidas: anunciava como uma revolução o movimento que derrubara Jango, mantinha a Constituição de 1946 com algumas modificações realizadas por ele, limitava o Congresso, suspendia garantias de estabilidade e vitaliciedade, previa instauração de inquérito e processo para apurar prática de crimes contra o Estado e concedia à junta militar o poder de cassar mandatos legislativos e suspender direitos políticos por dez anos.

Apesar do inicial e irrestrito apoio ao golpe, o primeiro Ato Institucional trouxe repercussão quase que unanimemente negativa da imprensa. Em um dos seus artigos, o Ato informava sobre a realização de novas eleições para Presidente e vice dentro de apenas dois dias, o que deixava clara a intenção de não abrir espaço para a formação de qualquer candidatura de oposição. 
A eleição indireta pelo Congresso Nacional fez de Castelo Branco presidente por esmagadora maioria. Durante seu governo, o Brasil rompeu relações diplomáticas com Cuba e contou com irrestrito apoio político e econômico dos Estados Unidos.

A gestão do primeiro Presidente do regime militar foi caracterizada pela obrigatoriedade de cumprimento das normas impostas pelo Ato Institucional e pelas cassações de políticos ligados a João Goulart, limando figuras ligadas ao governo deposto com a finalidade de eliminar toda e qualquer chance para que houvesse os avanços e as tão polêmicas reformas de base.

Houve afastamento e aposentadoria compulsória de diversos oficiais das Forças Armadas, prisão de cerca de cinco mil pessoas e afastamento de mais de mil funcionários públicos.

Em seu artigo oitavo, o Ato Institucional $\mathrm{n}^{\mathrm{o}} 1$ previa inquéritos $\mathrm{e}$ processos visando apuração da responsabilidade pela prática de crime contra o Estado. Tal disposição facilitou o surgimento de uma espécie de poder paralelo para os militares responsáveis por essas investigações.

Diante disso, era notório que o governo do general Castelo Branco era contraditório com relação às ideias democráticas e valores liberais que costumava pregar.

Economicamente falando, o governo tinha como programa a redução do déficit público, o arrocho de salários e controle do crédito. No mês de julho do mesmo ano, foi aprovada uma Emenda Constitucional $\mathrm{n}^{\mathrm{o}}$ 09, prorrogando o mandato de Castelo Branco até março de 1967.

A repressão política e o fracasso dos planos econômicos foram motivos que levaram ao descontentamento de muitos eleitores, ao passo que alguns estrategistas políticos acreditavam que o candidato de oposição é que seria eleito. 


\subsubsection{O Ato Institucional $n^{\circ} 2$}

Em 27 de outubro de 1965, Castelo Branco decretou o AI-2 após as eleições que ocorreram no início do mês. Através desse Ato foram emendados vários artigos da Constituição então vigente, tornando indireta a eleição para o cargo de Presidente da República.

O Poder Judiciário passou a sofrer direta intervenção do Poder Executivo: este poderia editar normas em qualquer momento, qualquer que fosse o seu conteúdo, ainda que não houvesse obediência ao ordenamento jurídico. Dessa forma, não havia qualquer segurança com relação às normas e legislação brasileira, dependentes do autoritarismo do regime militar, que por sua vez não passava por qualquer espécie de controle do Congresso Nacional.

Se havia divergência com relação ao conteúdo do AI-1, fica evidente, agora, com o Ato Institucional $\mathrm{n}^{\mathrm{o}} 2$, a maior repressão do novo regime, encaminhando-se para uma efetiva ditadura, uma vez que o Ato fortaleceu excessivamente o Poder Executivo e fez com que houvesse maior controle do Congresso e do Poder Judiciário. Reforçando, assim, o estado de exceção.

Logo em seguida e ainda durante o mandato de Castelo Branco, foram editados outros dois Atos Institucionais: AI-3 e AI-4. O primeiro previa agora a eleição indireta para governadores de estado e a nomeação dos prefeitos das capitais por eles, e o segundo convocava o Congresso Nacional a votar o Projeto Constitucional que deu origem à Constituição de 1967.

Ao que tudo indicava, nem tão cedo a sociedade brasileira voltaria a ter um Presidente da República democraticamente eleito e o regime militar parecia estar longe de acabar, com um conjunto de normas voltadas ao autoritarismo e à repressão. 


\subsubsection{O Ato Institucional $n^{\circ} 5$}

A teoria da funcionalidade da tortura baseia-se numa confusão entre interrogatório e suplício. Num interrogatório há perguntas e respostas. No suplício, o que se busca é a submissão. O "supremo opróbrio" é cometido pelo torturador, não pelo preso. Quando a vítima fala, suas respostas são produto de sua dolorosa submissão à vontade do torturador, e não das perguntas que ele the fez. ${ }^{10}$

O sucessor de Castelo Branco foi o general Arthur da Costa e Silva. A tensão política da época foi intensificada: o movimento mais ativo era o estudantil e o ano de 1968 ficou marcado como um período de grande contestação política.

O movimento estudantil passou a realizar protestos mais radicais contra a ditadura militar, e durante uma dessas reivindicações, mais especificamente pela melhoria das condições da alimentação fornecida a estudantes carentes, em 28 de março de 1968, houve a morte do estudante Edson Luis de Lima Souto por um policial militar.

Esse acontecimento fez com que se intensificassem ainda mais a indignação e revolta dos estudantes contra o regime imposto, que reagiram indo às ruas e, consequentemente, sendo covardemente reprimidos pelos militares, com saldo de mortos, presos e feridos.

Enquanto os estudantes partiam para o confronto, alguns setores mais progressistas da Igreja passaram a se expressar mais na defesa dos direitos humanos violados pelo regime. No mesmo período, ainda, houve a primeira greve operária desde o começo da ditadura militar: a greve dos metalúrgicos de Osasco.

Considerando toda essa reação, membros da "linha dura" pensavam em maneiras de intensificar a repressão para que pudessem sufocar tais movimentações que se insurgiam contra o regime militar.

\footnotetext{
${ }^{10}$ GASPARI, Elio. A ditadura escancarada. $2^{\text {a }}$ Ed. Rio de Janeiro: Intrínseca, 2014. p. 41.
} 
Foi decretado, então, em 13 de dezembro de 1968, o Ato Institucional $\mathrm{n}^{\mathrm{o}} 5$. O mais conhecido de todos eles, simboliza o período mais duro e de maior repressão de toda a ditadura militar, garantindo poderes aos governantes para que punissem arbitrariamente os supostos inimigos do regime.

Dentre outras medidas, o Presidente era autorizado a fechar o Congresso Nacional, as Assembleias Legislativas e as Câmaras dos Vereadores. Ao Presidente era permitido, ainda, decretar intervenção nos estados e municípios ainda que não estivessem presentes as limitações previstas na Constituição, e continuar cassando direitos políticos de qualquer cidadão por dez anos.

Outra disposição do Ato foi a suspensão, no caso de crimes políticos contra a segurança nacional, a ordem econômica e social e a economia popular, do habeas corpus. Além de tudo isso, foram proibidas manifestações na rua, bem como reuniões ideológicas.

No mesmo dia em que o AI-5 foi decretado houve o fechamento do Congresso, que só seria reaberto em 1969. Os autores desse Ato acreditavam que apenas por meio desse endurecimento no regime militar era possível conter atos subversivos que ameaçavam a continuidade do que chamavam de Revolução.

De acordo com esse Ato, além de o Poder Executivo legislar e executar as leis por ele mesmo outorgadas, não seria possível ter seus atos revisados e questionados pelo Poder Judiciário. Sem prazo de vigência definido, o Ato Institucional no 5 vigeu até 31 de dezembro de 1978.

Com o fechamento do congresso, se deu início o período mais sangrento do regime militar, em que ocorreram maior número de casos de censuras, homicídios, torturas, prisões arbitrárias e outras violações cometidas pelos agentes estatais. Segundo Gaspari, na ditadura a tortura foi 
instrumento extremo de coerção e extermínio, o último recurso da repressão política que o Ato Institucional $\mathrm{n}^{0} 5$ libertou das amarras da legalidade. Começaram os anos de chumbo.

Em 30 de outubro de 1969 assumiu a Presidência o general Emílio Médici. Apesar do AI-5 estar em vigor e a repressão em pleno vapor, nesse período o país cresceu economicamente e o governo passou a anunciar à população o "milagre econômico".

O Brasil, aberto ao capital estrangeiro, recebeu diversas empresas multinacionais e grandes fazendeiros passaram a exportar. Quem pagava o preço para a economia ir bem eram as pessoas de menor poder aquisitivo, com a sua alimentação prejudicada e a desnutrição chegando a patamares elevados.

No ano de 1974 foi a vez do general Ernesto Geisel assumir a Presidência. O milagre econômico chegava ao fim e, com ele, vinha a recessão e grande insatisfação popular. A crise do petróleo interferiu diretamente na economia brasileira, diminuindo os empréstimos e créditos internacionais e aumentando a dívida externa.

Os militares da linha dura mostravam-se descontentes com o governo de Geisel, que anunciou o início de uma abertura lenta, gradual e segura. Continuaram, então, agindo com a mesma violência dos anos anteriores. Uma morte simbólica que escandalizou a sociedade brasileira foi a do jornalista Vladimir Herzog, em 1975 no estado de São Paulo.

Em outubro de 1978 o AI-5 foi finalmente extinto por Geisel, juntamente com os demais Atos Institucionais. Era o início de um processo de distensão, gradual e vagarosamente abrandando aspectos autoritários impostos pelo regime. 


\subsection{Redemocratização}

No dia 15 de outubro de 1978 o colégio eleitoral elege o general João Batista Figueiredo como presidente. A crise econômica mundial ganhava contornos alarmantes e houve início de quebra da economia do Brasil.

Essa lenta transição de volta à democracia brasileira, portanto, foi um movimento organizado pelos militares - que pretendiam manter o controle da situação -, e não um movimento revolucionário realizado pelo povo.

O primeiro Congresso Nacional da Anistia ocorreu em São Paulo, no fim de 1978, e objetivava uma anistia ampla, geral e irrestrita a todos aqueles que sofreram perseguição política no período da ditadura militar.

Tal projeto de lei foi encaminhado ao Congresso Nacional pelo Presidente João Figueiredo e, após muita discussão e clima de tensão, foi aprovado e sancionado. Nasce, então, em 28 de agosto de 1979, a Lei ${ }^{\circ}$ 6.683/79, Lei de Anistia, com extensão aos crimes comuns praticados pelos agentes da repressão.

Em 1983 iniciou-se um dos movimentos mais importantes no que diz respeito à redemocratização do país: as Diretas Já. A campanha propunha eleições diretas para o cargo de Presidente da República, ganhando apoio de partidos como o PMDB e PDS e, em pouco tempo, conquistando também a população, que foi às ruas.

Apesar de reprimidos por membros do regime, não houve recuo. $\mathrm{O}$ movimento fez ressurgir uma esperança no povo brasileiro e, com ela, sua força e coragem. No dia emblemático de 25 de janeiro de 1984, mais de 1 milhão e meio de pessoas se reuniram e foram às ruas da capital de São Paulo para declarar apoio às Diretas Já e, com o mesmo propósito, em 10 de abril ocorreu o Comício da Candelária, no Rio de Janeiro, reunindo a 
mesma quantidade expressiva de pessoas que pediam a volta das eleições diretas para a Presidência da República.

Duas semanas depois, no dia 25 de abril de 1984, a Proposta de Emenda "Dante de Oliveira", que tinha como objetivo reinstalar as eleições diretas no Brasil foi derrotada no Congresso Nacional. A primeira vitória aconteceu em 15 de janeiro de 1985, e em um clima de comemorações, Tancredo Neves foi eleito Presidente da República, derrotando Maluf por 480 votos contra 180 .

A realidade é que as lideranças das Diretas Já passaram a compor a nova elite política do Brasil. A volta do poder civil ocorreu em 1985, na aprovação da nova Constituição Federal de 1988 e com a realização das eleições diretas para Presidente da República em 1989. 


\section{A Constituição Federal de 1988}

Essa é, em síntese, em essência, a Constituição de um país: a soma dos fatores reais do poder que regem um país.

Mas, que relação existe com o que vulgarmente chamamos Constituição; com a Constituição jurídica? Não é difícil compreender a relação que ambos conceitos guardam entre si.

Juntam-se esses fatores reais do poder, escrevemo-los em uma folha de papel, dáse-lhes expressão escrita e a partir desse momento, incorporados em um papel, não são simples fatores reais do poder, mas sim verdadeiro direito, nas instituições jurídicas e quem atentar contra eles atenta contra a lei, e por conseguinte é punido. ${ }^{11}$

\subsection{Assembleia Nacional Constituinte}

O fato é que as Diretas Já não ocorreram no ano de 1985. A chance de haver eleições diretas para Presidente da República poderia ter se concretizado por meio da Emenda Constitucional Dante de Oliveira pelo Congresso, que foi rejeitada por não alcançar o número mínimo de votos para a sua aprovação.

A votação, então, foi feita pelo Colégio Eleitoral o voto indireto para a Presidência da República, que elegeu Tancredo Neves com expressiva diferença. Por motivo de doença, todavia, Tancredo não pôde comparecer e tomar posse, vindo a falecer algum tempo depois, em 21 de abril de 1985.

José Sarney, vice-presidente da Aliança Democrática tomou, então, posse em seu lugar. Em 28 de junho de 1985, Sarney encaminhou mensagem ao Congresso Nacional, propondo a convocação de uma Assembleia Nacional Constituinte, dando origem à Emenda Constitucional $n^{\circ} 26$, de 27 de novembro de 1985.

Segundo José Afonso da Silva, em "Curso de Direito Constitucional Positivo":

\footnotetext{
${ }^{11}$ LASSALLE, Ferdinand. “Que é uma Constituição?”. São Paulo, 1933. p. 30.
} 
Em verdade, a EC n ${ }^{\circ}$ 26, de 27.11.85, ao convocar a Assembleia Nacional Constituinte, constitui, nesse aspecto, um ato político. Se convoca a Constituinte para elaborar Constituição nova que substituirá a que estava em vigor, por certo não tem natureza de emenda constitucional, pois esta tem precisamente sentido de manter a Constituição emendada. Se visava destruir esta, não pode ser tida como emenda, mas como ato político.

Tal Emenda trouxe, em seu artigo $4^{\circ}$, a concessão da anistia, bem como designava a promulgação da Constituição. Houve, então, o Decreto $\mathrm{n}^{0}$ 91.450, da data de 18 de julho de 1985, o qual determinou a Comissão Provisória de Estudos Constitucionais.

O Presidente da Comissão foi o jurista Afonso Arinos de Melo Franco, que, juntamente com os outros membros (cinquenta, no total), se debruçou na criação de um anteprojeto constitucional, entregue ao Presidente José Sarney.

Na data de 15 de novembro de 1986, a população foi às urnas e votou para eleger quem comporia a Constituinte, com um total de membros de 487 deputados e 72 senadores.

Foi instalada, então, em $1^{\circ}$ de fevereiro de 1987, a Assembleia Nacional Constituinte.

O regime militar foi responsável por instaurar uma crise de legitimidade de poder, dentre outros motivos devido às arbitrariedades cometidas, à instabilidade das esferas legislativa e executiva e completa desarmonia entre os direitos fundamentais e o poder do Estado.

Por ter estabelecido um regime constitucional desprendido do povo como fonte originária do poder, foi de grande relevância a invocação da Assembleia Constituinte, instalada com a finalidade de elaborar a nova Constituição brasileira.

Por meio dela, o povo - rechaçado do poder originário pelo regime militar - recupera o seu protagonismo no sistema constitucional brasileiro, 
tomando de volta para si o seu direito fundamental basilar do Estado Democrático de Direito.

Segundo José Afonso da Silva, em "Poder Constituinte e Poder Popular","poder constituinte é o poder que cabe ao povo de dar-se uma constituição. É a mais alta expressão do poder político, porque é aquela energia capaz de organizar política e juridicamente a nação" ${ }^{12}$.

O poder constituinte originário é inicial, incondicionado, permanente, uno e indivisível. Por isso, a instituição dessa Assembleia Nacional Constituinte é o apogeu da atuação do povo e de seu poder soberano.

A Constituição Federal foi, então, aprovada pela Assembleia Nacional Constituinte em 22 de setembro de 1988, e promulgada em 05 de outubro do mesmo ano.

\subsection{A Dignidade da Pessoa Humana}

\subsubsection{Aspecto Individualista}

Além de contextualizar, o capítulo anterior é fundamental quando partimos da premissa de que o direito deve ser compreendido historicamente.

Somado ao fim da Segunda Guerra Mundial - que consagrou a dignidade da pessoa humana no plano internacional ${ }^{13}$, toda violação e desrespeito aos direitos humanos fundamentais durante o regime militar contribuíram para que o legislador brasileiro incluísse a dignidade da

\footnotetext{
${ }^{12}$ SILVA, José Afonso da. Poder Constituinte e Poder Popular, p. 67.

${ }^{13}$ BARCELLOS, Ana Paula de. A Eficácia Jurídica das Normas Constitucionais, 2011, p. 130.
} 
pessoa humana como um dos fundamentos do Estado Democrático de Direito $^{14}$.

Art. $1^{\circ}$. A República Federativa do Brasil, formada pela união indissolúvel dos Estados e Municípios e do Distrito Federal, constitui-se em Estado Democrático de Direito e tem como fundamentos:

$$
\text { (...) }
$$

III - a dignidade da pessoa humana;

Parágrafo único. Todo o poder emana do povo, que o exerce por meio de representantes eleitos ou diretamente, nos termos desta Constituição. ${ }^{15}$

As constituições não estão presentes apenas nos regimes verdadeiramente democráticos, mas, ao analisarmos governos flagrantemente arbitrários, fica claro que muitos deles se escondem atrás delas para angariar seus objetivos.

A partir da segunda metade do século $\mathrm{XX}^{16}$, foi firmado o entendimento de que as normas constitucionais são dotadas de superioridade hierárquica, ou seja, são normas soberanas e fundamentam toda a ordem jurídica, de tal modo que existem para serem respeitadas e concretizadas, devido à sua natureza imperativa.

A Constituição de 1988 adotou em seu texto definições ideológicas e valorativas, isso porque a Carta é o documento que inaugura o novo Estado, sendo o responsável por criar as novas bases e fundamentos deste.

A Lei Fundamental da República Federal da Alemanha foi a primeira a dispor sobre a dignidade da pessoa humana, ao declarar, em seu artigo $1^{\circ}$,

\footnotetext{
${ }^{14}$ SILVA, José Afonso da. Poder Constituinte e Poder Popular, 2000, p. 144/145.

${ }^{15}$ Texto extraído da Constituição da República Federativa do Brasil de 1988, disponível no website $<$ http://www.planalto.gov.br/ccivil_03/constituicao/constituicaocompilado.htm>, acessado em 14/11/2016.

${ }^{16}$ BARCELLOS, Ana Paula de. A Eficácia Jurídica das Normas Constitucionais, 2011, p. 18.
} 
$\mathrm{n}^{\mathrm{o}} 1$, que "a dignidade humana é inviolável. Respeitá-la e protegê-la é obrigação de todos os poderes estatais ${ }^{17 "}$.

A dignidade da pessoa humana, segundo José Afonso da Silva, é "um valor supremo que atrai o conteúdo de todos os direitos fundamentais do homem, desde o direito à vida" ${ }^{18}$.

Seguindo a filosofia kantiana, o indivíduo não se constitui em objeto e nem deve ser tratado como um meio, mas considerado como um fim em si. De acordo com o filósofo, apenas por sua condição de ser humano, o homem possui direitos inerentes a ele - direitos humanos. Por sua condição singular, portanto, todos os seres humanos têm valor e dignidade.

Dessa forma, é cediço que a dignidade da pessoa humana não é um princípio criado pela Constituição, mas inerente e preexistente à condição de ser humano. O que faz a Carta de 1988 é reconhecer tal direito como princípio fundamental e basilar do Estado Democrático de Direito e da República Federativa do Brasil.

Além disso, importante ressaltar que a sua inserção não foi uma unanimidade da Constituição brasileira, mas que desde o fim da Segunda Guerra o direito internacional vem demonstrando maior preocupação com a temática dos direitos humanos e buscando maneiras eficazes para garanti-la.

A partir de uma leitura mais atenta da Constituição, do seu preâmbulo e principalmente de seus primeiros artigos, evidente que houve grande importância e centralidade conferida ao princípio da dignidade da pessoa humana se comparada aos demais bens jurídicos ${ }^{19}$.

Ainda segundo Ingo Wolfgang Sarlet:

Temos por dignidade da pessoa humana a qualidade intrínseca e distintiva de cada ser humano que o faz merecedor do mesmo respeito e consideração por parte do Estado e da comunidade, implicando, neste sentido, um complexo de

\footnotetext{
${ }^{17}$ SILVA, José Afonso da. Poder Constituinte e Poder Popular, p. 144.

${ }^{18}$ SILVA, José Afonso da. Curso de Direito Constitucional Positivo, 2012, $35^{\mathrm{a}}$ Ed.

${ }^{19}$ BARCELLOS, Ana Paula de. A Eficácia Jurídica das Normas Constitucionais, 2011, p. 164.
} 
direitos e deveres fundamentais que assegurem a pessoa tanto contra todo e qualquer ato de cunho degradante e desumano, como venham a lhe garantir as condições existenciais mínimas para uma vida saudável, além de propiciar e promover sua participação ativa e co-responsável nos destinos da própria existência e da vida em comunhão com os demais seres humanos mediante o devido respeito aos demais seres que integram a rede da vida. ${ }^{20}$

\subsubsection{Aspecto sistêmico}

Fundamental salientar que o princípio da dignidade humana é importante não somente em seu aspecto individualista, qual seja inerente à própria condição de ser humano, mas muito mais que isso: ele é um pilar do estado democrático de direito e se refere a ele mesmo.

Isso significa que a dignidade da pessoa humana é como um valor que permeia todo o sistema. Como todo princípio, ele deve ser capaz de alcançar todas as decisões e atitudes tomadas pelo Estado, ou seja, o princípio tem a ver com uma lógica sistêmica.

É essencial que essa outra face também seja respeitada, o que significa que, se com a redemocratização e o advento da Constituição de 1988 entramos em uma nova era, ou seja, se agora estamos inseridos em um estado de direito permeado pelo princípio da dignidade da pessoa humana, não é concebível que haja qualquer violação sistêmica deste, mas sua incansável preservação.

Por isso, quando não se respeita absolutamente o princípio da dignidade da pessoa humana e se permite atropelá-lo, sua inobservância ou até relativização é o mesmo que agir como um estado não-democrático de direito.

\footnotetext{
${ }^{20}$ SARLET, Ingo Wolfgang. Dignidade da Pessoa Humana e Direitos Fundamentais na Constituição Federal de 1988, 2011, p. 73.
} 


\subsection{Princípios Republicano e Democrático}

Montesquieu elenca como sendo três as formas de governo, quais sejam: o monárquico, o despótico e o republicano.

Para o filósofo, "o governo republicano é aquele no qual o povo em seu conjunto (...) possui o poder soberano", complementando, "quando, na república, o povo em conjunto possui o poder soberano, trata-se de uma Democracia" ${ }^{\prime 2}$.

A inserção do princípio republicano na Constituição de 1988 é consequência da aversão ao período de exceção vivido anteriormente, de modo a tentar concretizar os direitos fundamentais e a democracia.

Esses dois preceitos estão inseridos desde logo na Constituição, em seu artigo $1^{\circ}$, e garantem a responsabilidade dos agentes do Estado pelos atos que praticam, sua impessoalidade ao administrar os interesses públicos e o compromisso dos agentes públicos com a Lei.

Para que haja a observância do princípio democrático é necessário que os atos praticados pelos agentes estatais sejam dotados de legitimidade, que é garantida através do princípio da cidadania.

Cidadania é a possibilidade que o indivíduo tem de participar ativamente da vida política de seu país e exercer direitos e deveres civis e sociais.

Durante a era militar o direito à cidadania estava muito longe de sua plenitude. Ainda que o regime tentasse mascarar o autoritarismo através de eleições para o Legislativo e o Executivo, o governo extinguiu os mais basilares direitos de cidadania: havia censura de todos os tipos, doutrinamento ideológico e cassação e prisão de líderes políticos e sindicais.

\footnotetext{
${ }^{21}$ MONTESQUIEU, “O Espírito das Leis”, 2000, p. 19.
} 
Em uma república, portanto, os governantes devem agir de acordo com a vontade do povo e são nada mais que meros representantes destes, não podendo trabalhar de acordo com os seus próprios interesses e finalidades, mas deixando que prevaleça a soberania popular. 


\section{$4 \quad$ Lei de Anistia}

\subsection{O Instituto da Anistia}

A anistia se caracteriza pelo perdão concedido por uma autoridade a determinados indivíduos, geralmente em razão de crimes de circunstâncias políticas. O conceito desse instituto se exprime pelo próprio significado da palavra.

Anistia tem origem do grego amnestia, que significa "esquecimento", ou seja, é criada uma ficção jurídica de tal modo como se as condutas ilícitas não tivessem sido cometidas. Ela vem sendo aplicada desde a Grécia como uma forma de benevolência e esquecimento do passado, e desde então em inúmeros países ao redor do mundo. ${ }^{22}$

No Brasil foram vários os episódios de decretação de anistia desde o Império, tais como no Rio Grande do Sul aos revolucionários da revolta dos Farrapos e em Pernambuco aos revoltosos da Revolução Praieira. ${ }^{23}$

Àquela época a competência para decretação de anistia era do Imperador, dotado de Poder Moderador, que após a proclamação da República foi transferida para o Congresso. ${ }^{24}$

Durante o regime militar essa competência para concessão de anistia foi novamente modificada, fazendo com que fosse necessária a iniciativa do Presidente da República, ouvido o Conselho de Segurança Nacional. Já com a Constituição atual, a anistia é matéria de competência da União e cabe ao Congresso Nacional dispor sobre ela.

\footnotetext{
${ }^{22}$ LINS E SILVA, Evandro.Anistia. Disponível em $<$ http://www.fgv.br/cpdoc/acervo/dicionarios/verbete-tematico/anistia>, acesso em 14/11/2016 ${ }^{23}$ LINS E SILVA, Evandro.Anistia. Disponível em $<$ http://www.fgv.br/cpdoc/acervo/dicionarios/verbete-tematico/anistia>, acesso em 14/11/2016 ${ }^{24}$ Ibid.
} 


\title{
$4.2 \quad$ Lei 6.683 de 1979
}

Durante o regime militar, a pressão popular foi intensificada especialmente a partir de 1977, quando houve diversas manifestações estudantis, protestos, atuação da $\mathrm{OAB}$ e de algumas instituições religiosas, todos afim da reconstituição das liberdades democráticas.

Em 1978 já estavam presentes as condições para que houvesse a anistia ampla, geral e irrestrita. Além de toda movimentação social, foram criados os comitês brasileiros pela Anistia.

Estes comitês eram formados de maneira autônoma em cada estado, sem que houvesse uma centralização nacional, e organizados livremente no que diz respeito às suas organizações internas.

Seus objetivos consistiam, em primeiro lugar, em conquistar a anistia ampla, geral e irrestrita; depois, que fosse decretado o fim da Lei de Segurança Nacional e, por último, o direito de registro civil para os filhos dos exilados. $^{25}$

No mês de outubro de 1978 houve o I Congresso Nacional pela Anistia, em São Paulo, que enfatizou:

\begin{abstract}
Recusando o ponto de vista de uma anistia "recíproca", por julgarmos inteiramente imprópria, sem precedentes e extemporânea a utilização do instituto da Anistia para quem não foi identificado oficialmente, não sofreu qualquer sanção punitiva, não foi condenado, nem mesmo julgado. Consideramos, sim, que toda Nação deve tomar conhecimento dos crimes cometidos contra os Direitos Humanos e identificar seus responsáveis, para que possa repeli-los, num quadro de respeito aos direitos inalienáveis. $\mathrm{O}$ organismo social que foi gravemente corroído pelo vírus da tortura necessita tratar abertamente desta questão, para que a repulsa pública vacine-o contra novas acometidas no futuro. ${ }^{26}$
\end{abstract}

\footnotetext{
${ }^{25}$ COSTA, Marcelo. Comitê Brasileiro pela Anistia (CBA). Disponível em $<$ http://www.fgv.br/cpdoc/acervo/dicionarios/verbete-tematico/comite-brasileiro-pela-anistiacba>, acessado em 13/11/2016.

${ }^{26}$ Discurso de Luiz Eduardo Greenhalg na abertura do I Congresso Nacional pela Anistia. Disponível em <http://csbh.fpabramo.org.br/o-que-fazemos/memoria-e-historia/exposicoesvirtuais/abertura-do-i-congresso $>$, acessado em 13/11/2016.
} 
O II Encontro Nacional de Movimentos pela Anistia foi realizado no mês de março daquele mesmo ano sucedido pelo Congresso Internacional de Anistia no Brasil, ocorrido em Roma. Tal congresso endossou apoio pela anistia ampla, geral e irrestrita.

Todo esse trabalho da sociedade no sentido de se cobrar a anistia surtiu efeito: dia 28 de agosto de 1979 foi promulgada a Lei $\mathrm{n}^{\mathrm{o}}$ 6.683, decretando a anistia. Ocorre que, ao mesmo tempo em que foi uma conquista depois de intensa pressão social, a Lei de Anistia foi elaborada como uma carta de outorga.

Isso significa que ainda que tenha havido intensa pressão popular e todo um trabalho da sociedade no sentido de se cobrar a anistia, há de se falar que a transição política teve seu prosseguimento determinado pelos militares e a fim de alcançar seus próprios e exclusivos objetivos pessoais, e não por acreditarem, de maneira repentina, na importância de um regime democrático. $^{27}$

Dessa forma, para que houvesse verdadeiramente um acordo entre a sociedade civil e os civis e militares envolvidos no regime, seria necessário que ambas as partes tivessem participado integralmente desse acordo, e isso não ocorreu especialmente por dois motivos: ausência de legitimidade de uma parte e falta de autonomia da vontade da outra.

\subsection{Alcance dos anistiados e ADPF 153}

\subsubsection{Petição Inicial}

No ano de 2008 foi ajuizada pelo Conselho Federal da Ordem dos Advogados do Brasil (OAB) no Supremo Tribunal Federal a Arguição de

${ }^{27} \mathrm{CODATO}$, Adriano Nervo. Uma história política de transição brasileira: da ditadura militar à democracia". Revista de Sociologia e Política, nº 25. Curitiba: 2005. p. 3. 
Descumprimento de Preceito Fundamental $n^{0} 153$, que tinha como objeto o artigo $1^{\circ}, \S 1^{\circ}$, da Lei $6.683 / 79$, que regulamenta a anistia, e dispõe:

Art. $1^{\circ}$. É concedida anistia a todos quantos, no período compreendido entre 02 de setembro de 1969 e 15 de agosto de 1979, cometeram crimes políticos ou conexos com estes, crimes eleitorais, aos que tiveram seus direitos políticos suspensos e aos servidores da Administração Direta e Indireta, de fundações vinculadas ao poder público, aos Servidores dos Poderes Legislativo e Judiciário, aos Militares e aos dirigentes e representantes sindicais, punidos com fundamento em Atos Institucionais e Complementares (vetado).

$\S 1^{\circ}$ - Consideram-se conexos, para efeito deste artigo, os crimes de qualquer natureza relacionados com crimes políticos ou praticados por motivação política. $^{28}$

A ADPF questionou se o parágrafo do dispositivo questionado teria sido recepcionado pela Constituição de 1988 e se ele poderia ser interpretado de acordo com os fundamentos e preceitos da nova ordem constitucional. Em seu pedido, a OAB requereu ao Supremo Tribunal Federal:

Uma interpretação conforme a Constituição, de modo a declarar à luz dos seus preceitos fundamentais, que a anistia concedida pela citada lei aos crimes políticos ou conexos não se estende aos crimes comuns praticados pelos agentes da repressão contra opositores políticos, durante o regime militar (1964/1985) ${ }^{29}$

O Conselho Federal da OAB alegou, em primeiro lugar, que o dispositivo em questão foi redigido de maneira obscura, já com a intenção indireta de incluir como beneficiários da Lei os agentes públicos que cometeram crimes comuns durante o período ditatorial.

Depois, que além de a norma ter sido redigida intencionalmente com esse fim, ela é inepta. Isso porque crimes conexos são aqueles crimes que têm ligação entre si, ou seja, uma comunhão de propósitos objetivos (de acordo com o artigo 29 do Código Penal) e que, quando o artigo 76 do Código de Processo Penal reconhece a conexão criminal, é meramente

\footnotetext{
${ }^{28}$ Texto extraído da Lei $\mathrm{n}^{\circ} 6.683$ de 1979, disponível no website $<$ http://www.planalto.gov.br/ccivil_03/leis/L6683.htm>, acessado em 14/11/2016.

${ }^{29}$ Petição inicial da Ordem dos Advogados do Brasil, ADPF 153, 2008. p. 29.
} 
como regra de unificação de competência com o objetivo de não haver julgamentos contraditórios. Dessa forma, aqueles que eram contra a ditadura militar apenas lutaram contra o regime repressor que vigorava no país.

Em seguida, o Conselho Federal sustenta não existir qualquer conexão material entre os crimes políticos praticados pelos opositores da ditadura com os crimes comuns cometidos pelos militares. Como a anistia abarca apenas os autores de crimes políticos ou contra a segurança nacional, não há de se falar que os agentes públicos sejam abrangidos pela Lei.

Isso porque os crimes praticados contra seus opositores como tortura, estupro, homicídio e lesão corporal são crimes comuns - já que não houve comunhão de propósito entre eles e os crimes políticos. Os militares, portanto, não atentaram contra a ordem política e a segurança nacional, mas praticaram crimes comuns contra aqueles que se posicionaram contrários ao regime.

Além disso, argumenta que admitir que a anistia abrange tais agentes vai contra o preceito da nullum crimen sine lege,disposto no artigo $5^{\circ}$, XXXIX, da Constituição, já que o instituto da anistia não se volta a pessoas, mas a descriminalizar crimes previamente definidos por lei vigente à época da anistia.

Todavia, quando a Lei prevê a extensão de anistia àqueles que cometeram "crimes relacionados com crimes políticos" sem definir expressamente quais seriam eles, passa essa importante decisão para o Poder Judiciário, que estaria fazendo as vias do legislador. Tal situação configura uma afronta ao preceito fundamental de que não há crime sem lei anterior que o defina.

Ainda segundo o Conselho Federal da OAB:

Há os que praticaram crimes políticos, necessariamente definidos em lei, e foram processados e condenados. Mas há, também, os que cometeram delitos, cuja 
classificação e reconhecimento não foram feitos pelo legislador, e sim deixados à discrição do Poder Judiciário, conforme a orientação política de cada magistrado. Esses últimos criminosos não foram jamais condenados nem processados. Eles já contavam com a imunidade penal durante todo o regime de exceção. $\mathrm{O}$ que se quer, agora, é perpetuar essa imunidade, sem que se saiba ao certo quem são os beneficiários. ${ }^{30}$

É enfatizada, então, a redação do art. $1^{\circ}, \S 2^{\circ}$, da Lei $6.683 / 79$, que exclui do benefício da anistia "os que foram condenados pela prática de crimes de terrorismo, assalto, sequestro e atentado pessoal". Primeiro eles questionam o que exatamente seria crime de terrorismo, e se for conceituado como "a prática de violência generalizada", se perguntam se "por acaso, a prática sistemática e organizada, durante anos a fio, de homicídios, sequestros, tortura e estupro contra opositores políticos não configura terrorismo de Estado?" (grifo deles). ${ }^{31}$

Além de tudo o que foi argumentado até o presente momento, o Conselho Federal sustentou que o dispositivo em questão não poderia ser recepcionado pela Constituição Federal de 1988 por violar alguns preceitos fundamentais, que mencionarei a seguir.

O primeiro preceito citado é o da isonomia perante a lei em matéria de segurança. Isso porque existem aqueles que praticaram crimes políticos previamente definidos em lei e que, por isso, foram condenados pelo Judiciário, ao mesmo tempo em que há os que praticaram os crimes relacionados, não definidos e que não foram punidos nem ao menos processados. Ao admitir a interpretação questionada na ADPF, a Lei de Anistia declara que não são todos iguais perante a lei em matéria de anistia criminal.

Se acolhida a interpretação que inclui como beneficiários da anistia os agentes estatais, o Conselho Federal da OAB afirma:

\footnotetext{
${ }^{30}$ Petição inicial da Ordem dos Advogados do Brasil, ADPF 153, 2008. p.19.

${ }^{31}$ Petição inicial da Ordem dos Advogados do Brasil, ADPF 153, 2008. p.19.
} 
Nesse caso, é flagrante a desigualdade perante a lei em matéria de segurança. Pois, de um lado, temos delitos de opinião, excluídos os crimes de violência, enquanto de outro lado, beneficiando-se da mesma anistia, tornam-se impuníveis os crimes violentos contra a vida, a liberdade e a integridade pessoal. Pode-se configurar mais aberrante desigualdade? (grifo deles). ${ }^{32}$

O segundo preceito fundamental apontado por eles é o direito à informação, encontrado no art. $5^{\circ}$, XXXIII, que em sua redação literal dispões que "todos têm direito de receber dos órgãos públicos informações de seu interesse particular, ou de interesse coletivo ou geral".

Considerando que os governantes são nada mais que meros servidores do povo, estes não podem ocultar a verdade àquele que the delegou poder, o povo. Especialmente porque o objetivo maior do Estado deve ser exatamente o de propiciar o bem comum, colocando-o acima de quaisquer interesses pessoais do governo.

Sustenta, assim, que todos os governos do regime militar se esforçaram no sentido de manter o segredo sobre atos e comportamentos de agentes estatais que agiram fora da lei contra os seus opositores. E que, nesse sentido, a Lei $6.683 / 79$ foi promulgada nesse mesmo contexto, no último dos governos militares, e ao permitir que pessoas indeterminadas fossem anistiadas, obstou que as vítimas do regime militar e os seus familiares pudessem identificar os respectivos criminosos que, em regra, agiam com codinomes quando praticavam crimes comuns, e continua:

\begin{abstract}
Enfim, a lei assim interpretada impediu que o povo brasileiro, restabelecido em sua soberania (pelo menos nominal) com a Constituição de 1988, tomasse conhecimento da identidade dos responsáveis pelos horrores perpetrados, durante dois decênios, pelos que haviam empalmado o poder.
\end{abstract}

Ora, entre a Justiça e a Verdade não há separação concebível (grifo deles). ${ }^{33}$

Os princípios republicano e democrático são outros que, segundo o Conselho Federal da $\mathrm{OAB}$, são desrespeitados pelo dispositivo questionado.

\footnotetext{
${ }^{32}$ Ibid.

${ }^{33}$ Petição inicial da Ordem dos Advogados do Brasil, ADPF 153, 2008. p.21.
} 
É sabido por todos que o coração de um regime democrático é a soberania popular, cujo poder emana do povo, representado por seus governantes eleitos.

À época em que a Lei de Anistia foi votada pelo Congresso Nacional, este era composto por designados pelos comandantes militares. Ocorre que, em razão da Emenda que ficou conhecida como "Pacote de Abril" ${ }^{34}$, um terço dos senadores passaram a ser escolhidos por meio de eleições indiretas (os chamados "senadores biônicos") e foi sancionada por um general do exército, que atuava como Chefe de Estado.

Considerando essa ilegitimidade democrática, para que se pudesse produzir o efeito de anistia era necessário que, ao entrar em vigor a nova Constituição, o referido diploma legal tivesse sido legitimado seja pelo órgão legislativo proveniente de eleições diretas, seja pelo próprio povo por meio de referendo.

Uma vez que a soberania popular preceitua que os governantes têm que agir de acordo com o bem comum e nunca colocar seus interesses pessoais acima dele, estes não têm poder para anistiar criminalmente os agentes que cometeram crimes comuns sob o cumprimento de suas ordens.

Em seguida é citado o princípio da prevalência dos Direitos Humanos, que foi absolutamente violado pelos crimes comuns cometidos pelos agentes da Ditadura Civil Militar contra os opositores do regime. O Conselho Federal da $\mathrm{OAB}$ esclarece que tal princípio permeia a relação do Brasil com outros países no plano internacional, e indaga "porventura temos o direito de exigir de outros países o respeito aos direitos humanos, quando nos recusamos a respeitá-los em nosso próprio território?" 35

\footnotetext{
${ }^{34} \mathrm{~A}$ Emenda "Constitucional" ${ }^{\circ}$ 08, de 14 de abril de 1977, disponível no website $<$ http://www.planalto.gov.br/ccivil_03/Constituicao/Emendas/Emc_anterior1988/emc08-77.htm>, acessado em 14/11/2016.

${ }^{35}$ Petição inicial da Ordem dos Advogados do Brasil, ADPF 153, 2008. p.24.
} 
O próximo preceito que o Conselho Federal alega ter sido violado pelo dispositivo questionado é o da dignidade da pessoa humana, uma vez que ela não pode ser utilizada como um meio para qualquer que seja a finalidade, o que faz com que seja inconcebível defender que tal dispositivo foi um acordo para que se permitisse a transição do regime militar ao Estado Democrático de Direito.

Em primeiro lugar, a $\mathrm{OAB}$ questiona quem foram as partes nesse alegado acordo, uma vez que no momento em que a Lei de Anistia foi sancionada grande parte dos opositores do regime já estavam mortos, e que se utilizaram de delitos de opinião de maioria das vítimas ainda vivas para abafar a permissão de anistia àqueles agentes estatais que cometeram crimes.

Em segundo lugar, a Constituição de 1988 considerou "inafiançável e insuscetível de graça ou anistia a prática de tortura", segundo o art. $5^{\circ}$, XLIII. Nesse aspecto, não há que se argumentar que quando a Lei foi promulgada não havia a definição de tortura como crime no país, já que há uma flagrante incompatibilidade ético-jurídico radical entre ela e a dignidade da pessoa humana, protegida desde 1948, quando houve a Declaração Universal dos Direitos Humanos da ONU.

Por fim, aqueles que sofreram violações aos seus direitos humanos durante a Ditadura militar foram vítimas, e não criminosos que precisassem ser anistiados. Dessa forma, atos de violação à dignidade humana não se reparam apenas com uma mera indenização pecuniária.

\subsubsection{Síntese das informações dadas pela Câmara dos Deputados, Advocacia Geral da União e Senado Federal}

Quando solicitada para conceder informações, a Câmara dos Deputados foi sucinta e não enfrentou a questão, informando apenas que a 
Lei 6.683/79 foi aprovada na forma de projeto de lei do Congresso Nacional, sendo promulgada de acordo com o processo legislativo da época.

Já a Advocacia Geral da União, representada pela Sra. Ana Carolina de Almeida Tannuri Laferté e pelo Sr. Henrique Augusto Figueiredo Fulgêncio, adentrou no mérito da questão, aduzindo os seguintes argumentos.

Em primeiro lugar, alegam que anistia significa "esquecimento", e que apesar de, em regra, ser dirigida a crimes políticos, nada impede que ela seja concedida também a crimes comuns; isso porque a fim de apaziguar ódio e ressentimentos, seria muito mais proveitoso o esquecimento que a punição.

Ao passar à análise do contexto em que foi promulgada, defendem que a Lei $\mathrm{n}^{0}$ 6.689/79 é resultado de "uma negociação havida entre a sociedade civil e o regime militar, que possibilitou, à época, a transição para o regime democrático"36, de modo a beneficiar ambos os lados e fazendo por evitar qualquer tipo de "revanchismo" em um novo governo.

Complementa ainda que a vontade do legislador não passou desapercebida pelo Instituto dos Advogados Brasileiros em 30/05/1979, que considerou a anistia uma reconciliação da nação consigo mesma, devendo, por isso, ser irrestrita.

Relembra ainda que à época foi referendado também pela Ordem dos Advogados do Brasil, que declarou que "nem a repulsa à tortura obscurece a necessidade de reconhecer total amplitude emprestada a tal esquecimento penal".

\footnotetext{
36Íntegra das informações dadas pela Advocacia Geral da União, ADPF 153, 2008. p. 12. Disponível em $<$ file:///D:/Downloads/integra_da_manifestacao_da_agu.pdf $>$, acessado em 20/11/2016.
} 
Por isso, afirmam que a abrangência da Lei de Anistia decorre do contexto em que fora promulgada, sem que houvesse qualquer discriminação entre aqueles que lutaram contra o regime e os pertencentes a ele para concessão do benefício. Sendo assim, a interpretação que prevaleceria é a de que a anistia concedida pela lei 6.683/79 é ampla, geral e irrestrita.

Em seguida, argumentam que a anistia engloba todos os crimes comuns e políticos, desde que tenham sido praticados por razões políticas, e alegam que uma taxatividade seria contraditória ao próprio caráter da anistia, qual seja: amplo e irrestrito.

Além disso, aduzem que uma possível mudança de interpretação da legislação que contempla a anistia afrontaria a segurança jurídica, pois seria responsável por violar situações jurídicas definitivamente consolidadas e com seus efeitos já produzidos.

Não apenas esse princípio penal seria violado, de acordo com o Advogado Geral da União, mas o da irretroatividade da lei penal, uma vez que a mudança de entendimento acarretaria na leitura mais gravosa da norma.

Argumentam, ainda, que não há de se falar no fato de a Lei 6.683/79 ter sido aprovada por parlamentares escolhidos pelos comandantes militares, uma vez que o ato foi recepcionado pela atual Constituição de 1988, e isso dependeu apenas de sua compatibilidade material.

Com relação à alegação de que a Lei de Anistia inviabilizaria o direito à verdade, assim eles se posicionam:

Por fim, ressalte-se a insubsistência da alegação apresentada pelo requerente no sentido de que a lei hostilizada violaria a Constituição por impedir o acesso do 
povo brasileiro a informações sigilosas relativas ao período da ditadura. $\mathrm{O}$ sigilo a que alude o autor constitui matéria estranha à versada na Lei $n^{\circ} 6.683 / 79(\ldots){ }^{37}$

Enquanto isso, o Senado Federal também dissertou sobre o mérito da questão, no seguinte sentido.

Para eles, a Lei em questão já exauriu os seus efeitos imediatamente após a sua promulgação, de modo que não faria sentido a análise do Supremo Tribunal Federal se o dispositivo foi ou não recepcionado pela Constituição Federal.

Após, argumentam que para que se não abrangesse os crimes políticos, conexos ou praticados por motivação política seria necessário mudar o próprio conceito de anistia; e que é decorrente de um acordo político que, caso não tivesse havido, seria possível que não houvesse também a redemocratização.

Por fim, terminam argumentando que é insustentável invocar a Constituição Federal de 1988 para questionar a lei em questão, uma vez que a anistia faz cessar todos os efeitos penais do crime, o que ocorreu em 1979.

\subsubsection{Improcedência da ADPF e os votos dos ministros}

O Supremo Tribunal Federal, nos dias 28 e 29 de abril de 2010, julgou a ADPF e decidiu, por 7 (sete) votos a 2 (dois), pela improcedência da ação que questiona a aplicação da Lei de Anistia aos agentes estatais que cometeram crimes comuns durante o regime militar.

O relator foi o ministro Eros Grau, que depois de analisar as preliminares, passou ao mérito e proferiu os seguintes argumentos.

\footnotetext{
${ }^{37}$ Íntegra das informações dadas pela Advocacia Geral da União, ADPF 153, 2008. p. 23. Disponível em <file://D:/Downloads/integra_da_manifestacao_da_agu.pdf $>$, acessado em 20/11/2016
} 
Para ele, não cabe ao Poder Judiciário rever o acordo político que na transição do regime militar à democracia concedeu anistia a todos aqueles que cometeram crimes políticos no país no período de 02 de setembro de 1961 e 15 de agosto de 1979.

Rebate a alegação de que a lei tem caráter obscuro argumentando que todo texto normativo é obscuro até a sua interpretação e, portanto, é a interpretação de um texto legal que o transforma em norma.

Segundo o ministro, se houvesse de ocorrer tal revisão, esta deveria ser feita pelo Poder Legislativo, já que ao Supremo Tribunal Federal não compete legislar. Isso porque a anistia incorporou-se na nova ordem constitucional no Brasil pela Emenda n 26, de 27 de novembro de 1985, que convocou a Assembleia Nacional Constituinte.

Com relação ao argumento da $\mathrm{OAB}$ de que a interpretação dada ao dispositivo questionado viola o preceito da isonomia em matéria de segurança, o ministro alega que o que foi contestado não foi uma determinada interpretação do dispositivo, mas o próprio texto legal. Para Eros Grau, o argumento não prospera "porque há desigualdade entre a prática de crimes políticos e crimes conexos com eles. A lei poderia, sim, sem afronta à isonomia - que consiste também em tratar desigualmente os desiguais - anistiá-los, ou não, desigualmente". ${ }^{38}$

Em resposta ao argumento de que tal interpretação afrontaria o direito de receber de órgãos públicos informações de seu interesse particular, ou de interesse coletivo ou geral, o ministro afirma que é a objetividade que caracteriza a anistia, estando ela, portanto, ligada a fatos e não pessoas. Concedida, por isso, a pessoas indeterminadas.

\footnotetext{
38 Íntegra do voto do ministro relator Eros Grau ao julgar a ADPF 153, p. 19. Disponível em $<$ http://www.stf.jus.br/arquivo/cms/noticiaNoticiaStf/anexo/ADPF153.pdf $>$, acesso em 08/01/17.
} 
Para rebater a afirmação por parte da $\mathrm{OAB}$ de que os princípios democrático e republicano foram violados, Eros Grau alega que, caso isso procedesse,

"não apenas o fenômeno do recebimento - a recepção - do direito anterior à Constituição de 1988 seria afastado, mas também outro, este verdadeiramente um fenômeno, teria ocorrido: toda a legislação anterior à Constituição de 1988 seria, porém exclusivamente por força dela, formalmente inconstitucional". ${ }^{39}$

Ao tratar da dignidade da pessoa humana, o ministro inicia afirmando que é um argumento exclusivamente político, e não jurídico; e sustenta que não se pode indagar a legitimidade do acordo político que fez nascer a Lei de Anistia, já que isso seria o mesmo que tratar com desprezo todos aqueles que se manifestaram politicamente e lutaram pela anistia.

Para o ministro a inclusão da anistia à Constituição de 1988 é inquestionável, e tentou sustentar que outras legislações brasileiras sobre a anistia incluíram como beneficiários do instituto autores de "crimes conexos". Por fim, sustenta que a que pese o voto pela improcedência da ação, é necessário que não esqueçamos tal período histórico, para que não volte a acontecer.

Além do relator, votaram pela improcedência do pedido os ministros Marco Aurélio Mello, Ellen Gracie, Carmem Lúcia, Gilmar Mendes, Cesar Peluso e Celso de Mello.

Enquanto isso, apenas os ministros Ricardo Lewandowski e Ayres Britto defenderam a revisão da Lei de Anistia.

Em seu voto, o ministro Ricardo Lewandowski ressaltou o período histórico em que foi promulgada a Lei de Anistia, defendendo ter sido ela outorgada e editada em meio a um clima de grande insatisfação popular

\footnotetext{
39 Íntegra do voto do ministro relator Eros Grau ao julgar a ADPF 153, p. 23. Disponível em $<\mathrm{http} / /$ www.stf.jus.br/arquivo/cms/noticiaNoticiaStf/anexo/ADPF153.pdf $>$, acesso em 08/01/17.
} 
contra o regime autoritário, longe de ser parte de qualquer concessão mútua ou acordo.

Em seguida, começa a distinguir e listar as espécies de conexão criminal, alegando que ainda que o legislador da época tenha pretendido caracterizar conexão material entre ilícitos de natureza diversa cometidos por pessoas distintas e em situações diferentes, esse ato não foi bem sucedido do ponto de vista técnico-jurídico. Para ele, não é concebível estabelecer conexão material entre os delitos em análise, quais sejam os crimes políticos cometidos pelos opositores do regime militar e os delitos comuns praticados pelos agentes estatais.

Após isso, o ministro busca mostrar se os delitos cometidos pelos agentes do Estado eram de natureza política ou possuíam motivação política. Além de elencar todos os crimes praticados à época pelos agentes do Estado, conclui que ainda que se argumente que o país estava em uma situação de beligerância interna, "mesmo assim os agentes estatais estariam obrigados a respeitar os compromissos internacionais concernentes ao direito humanitário, assumidos pelo Brasil desde o início do século passado". 40

A fim de motivar o seu voto, Lewandowski apresenta o entendimento da Suprema Corte ao diferenciar os crimes políticos e comuns, e votou no sentido de parcial procedência da ação, de modo que se entenda que os agentes do Estado não estão incluídos na anistia, mas que cabe ao juiz ou ao tribunal, caso a caso, realizar uma abordagem mediante a adoção de critérios de preponderância e da atrocidade dos meios.

O ministro Ayres Britto iniciou a sua exposição com trecho de um poema de sua autoria, escrito há cerca de vinte anos atrás, em que dizia que “A humanidade não é o homem para se dar as virtudes do perdão. Em certas

\footnotetext{
40 Íntegra do voto do ministro Ricardo Lewandowski ao julgar a ADPF 153, p. 19. Disponível em $<$ http://www.democraciaetransicao.fadir.ufu.br/sites/democraciaetransicao.fadir.ufu.br/files/votoministro-lewandowski-ADPF\%20153.pdf $>$, acessado em 08/01/2017.
} 
circunstâncias, o perdão coletivo é falta de memória e de vergonha, convite masoquístico à reincidência", e explica:

"Eu quis dizer com isso que, de fato, a coletividade não é o indivíduo. No indivíduo, o perdão é virtude. Na coletividade, pode não ser virtude e ainda levá-la àquela situação tão vexatória do ponto de vista ético-humanístico de se olhar no espelho da história e ter vergonha de si mesma". ${ }^{41}$

Para ele, não havia ligação direta dos crimes políticos aos de caráter comum praticados pelos agentes estatais, cabendo ao juízo de conhecimento a incidência ou não da Lei de Anistia, em cada caso concreto.

Após isso, o ministro afirma que, de acordo com a Corte Interamericana de Direitos Humanos, os Estados-Partes da Convenção Interamericana de Direitos Humanos têm a obrigação de coibir lesões a esses direitos, e, caso não o façam, é gerada responsabilidade internacional do Estado.

Ayres Britto aborda, ainda, o instituto da recepção, em que toda norma promulgada em data anterior a da Constituição deve estar de acordo com ela. Considerando o artigo $5^{\circ}$, XLIII, que veda a concessão da anistia ao "tráfico ilícito de entorpecentes e drogas afins, o terrorismo, a tortura e os definidos como crimes hediondos, por eles respondendo os mandantes, os executores e os que, podendo evitá-los, se omitirem", para o ministro, o artigo objeto da ADPF não poderia ter sido sequer recepcionado por ela.

Por fim, o ministro afirma que o que deve prevalecer é a vontade objetiva da lei, e não a vontade subjetiva do legislador. Com isso, Carlos Ayres Britto vota pela parcial procedência da ADPF, de modo a excluir do texto qualquer interpretação que entenda abranger a anistia aos crimes previstos no artigo $5^{\circ}$, inciso XLIII da Constituição.

\footnotetext{
41 Íntegra do voto do ministro Ayres Britto ao julgar a ADPF 153, p. 135. Disponível em $<$ http://redir.stf.jus.br/paginadorpub/paginador.jsp?docTP $=\mathrm{AC} \&$ docID $=612960>$, acessado em 08/01/2017.
} 
O resultado da Arguição de Descumprimento de Preceito Fundamental foi, então, improcedente por 7 (sete) votos a 2 (dois), rejeitando o pedido da Ordem dos Advogados do Brasil por uma revisão da Lei de Anistia. 


\section{Conclusão}

As feridas até hoje não fecharam, já que os responsáveis pela institucionalização da tortura - condenada por todas as convenções internacionais da guerra - ainda não foram todos identificados e punidos. Ao contrário, todos aqueles que lutaram contra o regime, foram perseguidos, torturados, mortos ou exilados. Nesse sentido, o golpe ainda não terminou. ${ }^{42}$

É possível verificar que enfatizamos neste trabalho a inserção no contexto histórico anterior ao golpe, do regime militar e da redemocratização, a inclusão de princípios basilares da Constituição de 1988, a exposição de aspectos relevantes da Lei 6.683 e a síntese dos argumentos utilizados na ADPF 153 e na decisão do Supremo Tribunal Federal.

A partir de toda essa análise, algumas conclusões merecem ser explicitadas.

Em primeiro lugar, é evidente que a Lei de Anistia foi promulgada em um contexto de transição política que, apesar de ter sido cobrada intensamente por parte da sociedade, foi dirigida pelos civis e militares pertencentes ao regime.

Esse processo de distensão teve seu andamento determinado pelos governantes da época, de modo que atendesse especialmente às suas necessidades pessoais. Isso já faz com que, por si só, questionemos a razão de serem incluídos como beneficiários do instituto da anistia de maneira tão ampla aqueles que cometeram "crimes conexos".

Além disso, incluir na anistia os crimes comuns perpetrados pelos agentes militares ofende desarrazoadamente o princípio da dignidade da pessoa humana tanto em uma lógica individualista como sistêmica.

\footnotetext{
${ }^{42}$ SANDER, Roberto. "1964: O Verão do Golpe".p.245.
} 
A primeira é a mais flagrante: é sabido que foram praticados crimes como tortura, estupro, homicídios qualificados e outros hediondos. Ora, como pode ser possível anistiar aqueles que os praticaram sem que se desrespeite por inteiro a dignidade inerente à própria condição de ser humano? Ao permitir isso, estão sendo perdoados crimes carregados de violação à dignidade da pessoa humana e, entre uma ponderação entre o instituto da anistia e este princípio, o último prevalece.

Mais especificamente sobre a tortura, por si só ela já é um crime que viola a dignidade. Assumindo isso, perdoá-la é o mesmo que permitir que se propague e persista e, portanto, uma afronta a este princípio.

Na nossa Constituição, no art. 5 XLIII, temos a seguinte redação:

Art. $5^{\circ}$ Todos são iguais perante a lei, sem distinção de qualquer natureza, garantindo-se aos brasileiros e aos estrangeiros residentes no País a inviolabilidade do direito à vida, à liberdade, à igualdade, à segurança e à propriedade, nos termos seguintes:

XLIII - a lei considerará crimes inafiançáveis ou insuscetíveis de graça ou anistia a prática de tortura, o tráfico ilícito de entorpecentes e drogas afins, o terrorismo e os definidos como crimes hediondos, por eles respondendo os mandantes, os executores e os que, podendo evitá-los, se omitirem; (grifo meu). ${ }^{43}$

Por essa própria lógica que imbuímos sobre a anistia, percebemos que há alguns crimes que simplesmente não podem ser perdoados. No caso dos agentes militares, há de se falar que formalmente eles já não poderiam ter sido anistiados, de acordo com a nossa Constituição.

Não apenas há a impossibilidade de ser aplicada formalmente, mas essa regra nos prova que nesses crimes há a violação da dignidade da pessoa humana e que, por isso, a anistia não pode ser aplicada.

Na lição de Celso Antônio Bandeira de Mello, "estuprar, matar, desintegrar física e moralmente uma pessoa em lugar nenhum da terra pode

\footnotetext{
${ }^{43}$ Texto extraído da Constituição da República Federativa do Brasil de 1988, disponível no website $<$ http://www.planalto.gov.br/ccivil_03/constituicao/constituicaocompilado.htm $>$, acessado em $14 / 11 / 2016$.
} 
ser entendido como um crime político. Trata-se evidentemente de um ato abjeto, infra-humano, inconfundível". ${ }^{44}$

Além disso, o próprio contexto da execução dos crimes perpetrados pelos militares eleva a gravidade deles. Em geral, crimes políticos que recebem indulto ou anistia têm um contexto no qual foram praticados e, em geral, não são abomináveis - já que caso o fossem, não seriam contemplados pelo instituto.

No caso dos militares, o próprio contexto e motivo pelos quais os crimes foram cometidos violam o princípio da dignidade da pessoa humana. Por isso, anistiá-los seria uma maneira de ferir os direitos humanos de uma forma geral, já que os crimes foram claramente atentatórios ao princípio.

Além desse aspecto individualista, devemos ter em mente que a dignidade da pessoa humana é um dos princípios basilares que permitem a existência do estado democrático de direito e é fundamental que essa face do princípio também seja respeitada.

Por isso, devemos nos lembrar que todos os crimes foram perdoados: ampla e irrestritamente. É uma anistia praticamente sistêmica. Ocorre que anistiar todos esses crimes é o mesmo que anistiar todo o contexto histórico de cometimento deles, o que é extremamente gravoso.

Isso significa que não são apenas todos esses crimes que serão anistiados (e já seria muito), mas ao perdoá-los estamos anistiando todo esse período. Estamos anistiando todo o contexto da ditadura civil militar, contexto este que feriu abruptamente os direitos humanos.

Essa decisão de abranger os militares na anistia é tão gravosa porque ao fazer isso, permitimos que flagrantes atentados aos direito humanos mais

\footnotetext{
${ }^{44}$ MELLO, Celso Antônio Bandeira de. Imprescritibilidade dos crimes de tortura. In: SOARES, Inês Virgínia Prado; KISHI, Sandra Akemi Shimada (Coord.). Memória e verdade: a justiça de transição no Estado Democrático brasileiro. Belo Horizonte: Fórum, 2009. cap. 6, p. 136.
} 
básicos sejam perdoados. Devemos ter em mente que a partir do momento que entramos em uma nova era permeada pelo princípio da dignidade da pessoa humana e respeito aos valores fundamentais do ser humano, todas as decisões do Estado devem ser baseadas e fundamentadas nesses valores.

A dignidade da pessoa humana é um princípio no sentido mais literal da palavra, ou seja, ela permeia todo o Estado. Está diretamente relacionada com essa lógica sistêmica, de que agora estamos inseridos em um Estado de direito que respeita os princípios fundamentais.

Não se pode permitir que uma violação sistêmica a esse princípio tão fundamental seja perdoada. Um Estado Democrático de Direito tem que ter um respeito absoluto à dignidade da pessoa humana. Ele não tem que ser respeitado apenas na esfera individual, mas permear todo o Estado, já que é um dos pilares dele. Perdoar esses crimes, portanto, é agir como um estado não-democrático de direito, porque basicamente o que está sendo feito é anistiar todo o período do regime militar.

Outro aspecto fundamental é o que diz respeito ao nosso direito internacional. A Corte Interamericana de Direitos Humanos teve sua jurisdição reconhecida pelo Brasil no Decreto Legislativo no 89 do ano de 1998, e considerou que é nula e sem qualquer efeito a auto-anistia criminal decretada por governantes, ao menos em cinco casos distintos. ${ }^{45}$

Em um deles e de suma importância, na data de 14 de dezembro de 2010, a Corte Interamericana de Direitos Humanos publicou sentença do caso da Guerrilha do Araguaia ${ }^{46}$, contrariamente à interpretação do STF acerca da Lei de Anistia, de modo a obrigar o Estado brasileiro a investigar

\footnotetext{
${ }^{45} \mathrm{CIDH}$, caso LoayzaTamayo v. Peru, de 27/11/1998, caso Barrios Altos v. Peru, de 14/03/2001, caso Barrios Altos, interpretacion de La sentencia de Fondo, de 03/09/2001, caso de La ComunidadMoiwana, de 15/09/2005, e caso AlmonacidAreliano y otros v. Chile, de 26/09/2006. ${ }^{46} \mathrm{~A}$ Guerrilha do Araguaia foi um movimento guerrilheiro de resistência à ditadura, organizada pelo Partido Comunista do Brasil (PCB) às margens do Rio Araguaia, região norte do estado de Tocantins. Apesar de apoio daqueles que lá residiam, o movimento tinha força bélica precária e terminaram massacrados pelo regime, que usou como argumento para aniquilá-los o "terrorismo".
} 
as violações de direitos humanos cometidas no país. Sendo assim, cabe ao Estado brasileiro executar a sentença, uma vez que ao deixar de fazê-lo estará desrespeitando uma decisão de um órgão cuja jurisdição já foi reconhecida e, por isso, indo de encontro ao comportamento que se espera de um país que respeite os acordos fixados no plano internacional.

"Em verdade, embora não existam mecanismos de coerção, deve-se afirmar que o descumprimento das decisões da Corte Interamericana trata-se de um comportamento inimaginável para um Estado que caminhe no sentido de respeitar os acordos firmados no plano das relações internacionais. Nunca é demais lembrar que o Brasil se comprometeu a cumprir integralmente as decisões da Corte no exercício de sua soberania e em total conformidade para com a ordem constitucional. Como se manifestou na Carta aos Três Poderes da República e ao Ministério Público Federal pelo Cumprimento Integral da Sentença da Corte Interamericana de Direitos Humanos no Caso Gomes Lund, assinada por familiares de mortos e desaparecidos políticos, ex-presos e perseguidos políticos, entidades da sociedade civil, juristas, intelectuais, artistas e defensores dos direitos políticos, entidades da sociedade civil, juristas, intelectuais, artistas e defensores dos direitos humanos, datada de $1^{\circ}$ de março de 2011: "Para deixar de cumpri-la, [o Brasil] deverá denunciar a Convenção, protagonizando com isso o mais grave retrocesso do Continente em matéria de direitos humanos". Não é preciso argumentar muito para se perceber que o atual comportamento contraditório do Estado brasileiro, reconhecendo o órgão jurisdicional internacional, mas não executando as suas decisões, mostra-se algo bastante - no mínimo - extravagante". ${ }^{47}$

Para a Corte, em respeito aos direitos das vítimas e de seus familiares, os crimes contra a humanidade cometidos pelos agentes do Estado devem ser investigados, processados e devidamente punidos. Ora, como podemos pretender participar de convenções sobre os direitos humanos se os mesmos não são respeitados dentro do nosso próprio território?

\section{Na lição de Flávia Piovesan,}

A absoluta proibição da tortura, o direito à verdade e o direito à justiça estão consagrados nos tratados internacionais, impondo ao Estado brasileiro o dever de investigar, processar, punir e reparar graves violações a direitos humanos, especialmente em se tratando de crime internacional. Leis de anistia não podem autorizar a manifesta violação a jus cogens, como a absoluta proibição da tortura, no plano internacional. Assegurar os direitos à verdade e à justiça é condição

\footnotetext{
${ }^{47}$ AYRES, Rodrigo Santa Maria Coquillard. Lei de Anistia e a Guerrilha do Araguaia: interação e consequências. Revista Jus Navigandi. Disponível em: <https://jus.com.br/artigos/36905>. Acesso em 08/01/2017.
} 
essencial para fortalecer o Estado de Direito, a democracia e o regime de direitos humanos no Brasil. ${ }^{48}$

Há quem argumente, ainda, que seria uma afronta ao princípio da segurança jurídica a mudança de interpretação da Lei de Anistia, uma vez que impactaria em situações já consolidadas juridicamente. Ocorre que não faz nenhum sentido entender que a segurança jurídica permitiria a proteção de atos flagrantemente criminosos por meio de uma auto-anistia, e que em uma ponderação entre este princípio e os direitos humanos, certamente os últimos prevalecem.

Àqueles que sustentam que temos que interpretar a vontade do legislador à época de sua elaboração, importante relembrar que os membros do Congresso Nacional responsáveis pela Lei eram ilegítimos: além de estarem absolutamente subordinados à ditadura e sob o comando dos militares, essa falta de legitimidade é reforçada pelo fato de que, a partir de 1977, um terço dos senadores era escolhido por vias indiretas.

Participaram, portanto, do processo legislativo da Lei de Anistia os chamados "senadores biônicos". Sem falar, ainda, que durante o regime militar não havia o pleno exercício de cidadania, o que reforça ainda mais a ilegitimidade daqueles legisladores, que deveriam ser meros representantes do povo e atender os seus anseios.

Essa ausência de cidadania nos faz entrar em outro ponto importante: o desrespeito aos princípios republicano e democrático, basilares na nossa Constituição. Como dito, a transição política foi realizada pelos militares de modo que atendesse às suas próprias finalidades, e foi nesse contexto que houve a promulgação da Lei 6.683/79.

\footnotetext{
${ }^{48}$ PIOVESAN, Flávia. "Lei de Anistia, Direito à Verdade e à Justiça: o Caso Brasileiro". Artigo disponível em $<\mathrm{http}$ ://interessenacional.com/index.php/edicoes-revista/lei-de-anistia-direito-averdade-e-a-justica-o-caso-brasileiro>, acesso em 15/11/2016.
} 
Ao anistiar criminalmente os agentes estatais responsáveis por cometer os crimes comuns já descritos neste trabalho, o Estado deixou de agir visando o bem comum do povo, mas objetivando o atendimento de seus próprios interesses; tal situação afronta, consequentemente, o princípio democrático, uma vez que os governantes são nada mais que meros representantes dos anseios da sociedade.

Com relação ao argumento de que a anistia recíproca foi parte de um acordo para que se restabelecesse a democracia, ressalto: ainda que assim entendamos, a dignidade da pessoa humana é irrenunciável e intransmissível, ou seja, ela não pode ser trocada por qualquer fim, ainda que a redemocratização.

Fica, pois, clara a incongruência da decisão do Supremo Tribunal Federal ao julgar improcedente a ação. Por fim, a ADPF n ${ }^{\circ} 153$ não objetiva alterar a Lei de Anistia, mas somente lhe conceder a devida interpretação conforme a Constituição de 1988 , de modo a que não se inclua no rol de proteção aqueles agentes estatais cujos crimes cometidos feriram a dignidade, a integridade moral e física e a vida dos cidadãos brasileiros.

Conclui-se, portanto, que os agentes militares que praticaram crimes comuns como tortura, estupro e homicídio não deveriam ser abrangidos pelo instituto da anistia disposto na Lei 6.683/79. Isso especialmente por violar princípios basilares da nossa Constituição e do Estado Democrático de Direito, Estado esse que tem o dever de investigar, processar e punir devidamente todas as violações aos direitos fundamentais perpetradas, que certamente não são compensadas apenas com a reparação pecuniária. 


\section{REFERÊNCIAS BIBLIOGRÁFICAS}

BARCEllos, Ana Paula de. A Eficácia Jurídica dos Princípios Constitucionais. Rio de Janeiro: Renovar, 2011.

BENEVIDES, Maria V. O governo Jânio Quadros. São Paulo: Brasiliense, 1981.

BONAVIDES, Paulo; ANDRADE, Paes de. História Constitucional do Brasil. Rio de Janeiro: Editora Paz e Terra, 1991.

CODATO, Adriano Nervo. Uma História Política da Transição Brasileira: da Ditadura Militar à Democracia. Revista de Sociologia e Política, Curitiba, no 25, p. 83-106, nov.2005. Disponível em: $<$ http://dx.doi.org/10.1590/S0104-44782005000200008>, acesso em 20 de maio 2016.

COSTA, Marcelo. Comitê Brasileiro pela Anistia (CBA). Disponível em $\quad<$ http://www.fgv.br/cpdoc/acervo/dicionarios/verbetetematico/comite-brasileiro-pela-anistia-cba>, acessado em $13 / 11 / 2016$.

DREIFUSS, Rene. 1964: A Conquista do Estado. Petrópolis: Vozes, 1981.

FERREIRA, Jorge. João Goulart, uma biografia. Civilização Brasileira, 2011. 
FICO, Carlos. Versões e Controvérsias sobre 1964 e a Ditadura Militar. Revista Brasileira de História, volume 24, n 47. São Paulo, 2004.

GASPARI, Elio. A Ditadura Envergonhada. São Paulo: Companhia das Letras, 2002.

. A Ditadura Escancarada. Intrínseca, 2a edição. Rio de Janeiro, 2014.

.A Ditadura Derrotada. Companhia das Letras. São Paulo, 2002.

.A Ditadura Encurralada. Companhia das Letras. São Paulo, 2004.

. A Ditadura Acabada. Intrínseca, $1^{\mathrm{a}}$ edição. Rio de janeiro, 2016.

LASSALLE, Ferdinand. Que é uma Constituição?São Paulo: Edições e Publicações Brasil, 1933.

MONTESQUIEU. O Espirito das Leis. São Paulo: Martins Fontes, 2000. 
PIOVESAN, Flávia. Lei de Anistia, Direito à Verdade e à Justiça: o Caso Brasileiro. Artigo disponível em $<$ http://interessenacional.com/index.php/edicoes-revista/lei-de-anistiadireito-a-verdade-e-a-justica-o-caso-brasileiro $>, \quad$ acesso em $15 / 11 / 2016$.

REIS, Daniel Aarão. Ditadura Militar, Esquerdas e Sociedade. Rio de Janeiro: Jorge Zahar, 2000.

RIBEIRO, Maria do Carmo Freitas. O Regime Jurídico da Lei de Anistia: Breves Anotações. Revista da SJRJ, Rio de Janeiro, n 27, p.95-105, 2010.

SANDER, Roberto. 1964: O Verão do Golpe. $2^{\mathrm{a}}$ ed. Editora Maquinária, Rio de Janeiro, 2013.

SARLET, Ingo Wolfgang. Dignidade da Pessoa Humana e Direitos Fundamentais na Constituição Federal de 1988, Porto Alegre: Livraria do Advogado Editora, 2011.

SARMENTO, Daniel. Dignidade da Pessoa Humana - Conteúdo, Trajetórias e Metodologia.Belo Horizonte: Fórum, 2016.

SKIDMORE, Thomas. Brasil: de Getúlio Vargas a Castelo Branco. São Paulo: Companhia das Letras, 2010.

SILVA, José Afonso da. Curso de Direito Constitucional Positivo. 9 ed. rev. São Paulo: Malheiros, 2007. 
. Poder Constituinte e Poder Popular. São Paulo:

Malheiros Editores Ltda, 2002.

TOLEDO, Caio N. O Governo Goulart e o Golpe de 64. São Paulo: Companhia das Letras, 2010. 